UNC -5198

AN AEC RESE ARCH AND

DEVELOPMENT REPORT

\title{
POST-IRRADIATION EXAMINATION OF HIGH-DENSTTY (UPU)C PELLET-FUELED EBR-II RODS IRRADIATED TO 30,000 Mwd/T
}

D. Stahl and A. Strasser

Project Engineer: D. Stahl

January 24, 1968

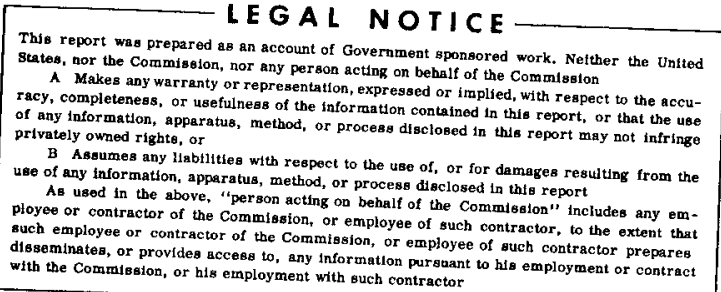

Work Performed under UNC Project 2335

Contract AT(30-1)-3415 with the

New York Operations Office of the

United States Atomic Energy Commission

UNITED NUCLEAR CORPORATION

Research and Engineering Center

Elmsford, New York 
Work Performed by

United Nuclear Corporation

B. Cherry

D. Stahl

A. Strasser
Battelle Memorial Institute (Columbus, Ohio)

R. Martin

V. Storhok

4 


\section{DISCLAIMER}

This report was prepared as an account of work sponsored by an agency of the United States Government. Neither the United States Government nor any agency Thereof, nor any of their employees, makes any warranty, express or implied, or assumes any legal liability or responsibility for the accuracy, completeness, or usefulness of any information, apparatus, product, or process disclosed, or represents that its use would not infringe privately owned rights. Reference herein to any specific commercial product, process, or service by trade name, trademark, manufacturer, or otherwise does not necessarily constitute or imply its endorsement, recommendation, or favoring by the United States Government or any agency thereof. The views and opinions of authors expressed herein do not necessarily state or reflect those of the United States Government or any agency thereof. 


\section{DISCLAIMER}

Portions of this document may be illegible in electronic image products. Images are produced from the best available original document. 
TABLE OF CONTENTS

1. INTRODUCTION . . . . . . . . . . . . . . . . 1

2. SUMMARY AND CONCLUSTONS . . . . . . . . . . . . 3

3. EXPERIMENT DESCRIPTION AND OPERATION . . . . . . . . . . . 5

4. POST-IRRADIATION EXAMINATION . . . . . . . . . . . . . 15

4.1 Fuel Rod Performance . . . . . . . . . . . . . . . . . . . . 17

4.1.1 Visual Examination . . . . . . . . . . . . . . . 17

4.1.2 Clad Measurement . . . . . . . . . . . . . 17

4.1.3 Gamma Scanning . . . . . . . . . . . . . . . 23

4.1.4 Fission Gas Release . . . . . . . . . . . . . . 23

4.2 Fuel Performance . . . . . . . . . . . . . . . . . . . 25

4.2.1 Visual Examination . . . . . . . . . . . . . . . 25

4.2.2 Dimensional Changes . . . . . . . . . . . . . . 25

4.2.3 Structure . . . . . . . . . . . . . . . . . . 29

4.2.4 Plutonium and Fission Product Distribution . . . . . . . . 32

4.2.5 Burnup Analysis . . . . . . . . . . . . . . . . . . . . 36

4.2.6 Temperature Analysis. . . . . . . . . . . . . 36

4.3 Clad Performance . . . . . . . . . . . . . . . . . . . . 43

4.3.1 Structure and Compatibility . . . . . . . . . . . . . 43

4.3.2 Microhardness . . . . . . . . . . . . . . . . 47

4.3.3 Bend Tests . . . . . . . . . . . . . 47 47

5. REFERENCES . . . . . . . . . . . . . . 49

\section{TABLES}

1. Characterization of $\left(\mathrm{U}_{0.8} \mathrm{Pu}_{0.2}\right) \mathrm{C}$ Pellets . . . . . . . . . . . 6

2. Summary of Irradiation Conditions . . . . . . . . . . . . . . . 7

3. Summary of Post-Irradiation Examination Results . . . . . . . . . 16

4. Post-Irradiation Clad Diameter Measurements of

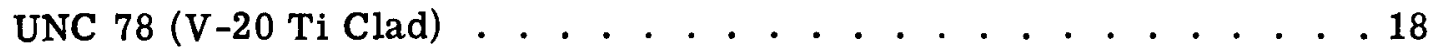


5. Post-Irradiation Clad Diameter Measurements of UNC 79 (Type 316 Clad)

6. Post-Irradiation Clad Diameter Measurements of UNC 80 (V Clad) . . . . . . . . . . . . . . . . . . . . . 20

7. Summary of Clad Diameter Changes . . . . . . . . . . . . . . . 24

8. Immersion Densities of Pellets . . . . . . . . . . . . . . . . . 30

9. Summary of Burnup Analyses . . . . . . . . . . . . . . . . . . . 37

10. Knoop Microhardness of Clads . . . . . . . . . . . . . . . . . . 48

\section{FIGURES}

1. Typical $\left(\mathrm{U}_{0.8} \mathrm{Pu}_{0.2}\right) \mathrm{C}$ Fuel Pellets . . . . . . . . . . . . . . 8

2. Cross-Sectional View of Typical EBR-II $\quad \ldots . . . . . . . . .99$

3. UNC 78 Performance Summary . . . . . . . . . . . . . . . . . 10

4. UNC 79 Performance Summary . . . . . . . . . . . . . . . . . . 11

5. UNC 80 Performance Summary . . . . . . . . . . . . . . . . . . 12

6. Positions of UNC Rods in EBR-II Subassembly . . . . . . . . . . . 14

7. Thin Crack near UNC 78 Bottom End Plug Weld . . . . . . . . . . . 21

8. Comparison of Calculated and Actual Clad

Strain vs Burnup . . . . . . . . . . . . . . . . . . . . . . . . . 22

9. UNC 79 during Decladding . . . . . . . . . . . . . . . . . . 26

10. UNC 80 Partially Declad . . . . . . . . . . . . . . . . . . 26

11. Whole Pellets from UNC 78 . . . . . . . . . . . . . . . . . 27

12. Typical Broken Fuel Pellet from UNC 79 . . . . . . . . . . . . . . 28

13. Typical Void Distribution in Fuel Pellets . . . . . . . . . . . . . . 31

14. Typical Fuel Structure (UNC 78, Pellet 7)

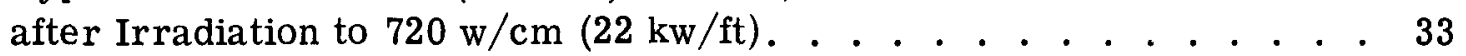

15. Typical Fuel Structure (UNC 80, Pellet 9) after Irradiation to $760 \mathrm{w} / \mathrm{cm}(23 \mathrm{kw} / \mathrm{ft})$. . . . . . . . . . . . . . 34

16. Typical Fuel Structure (UNC 80, Pellet 27) after Irradiation to $920 \mathrm{w} / \mathrm{cm}(28 \mathrm{kw} / \mathrm{ft})$. . . . . . . . . . . . . . 35

17. Typical Plutonium and Fission Product Distribution (UNC 78, Pellet 2) after Irradiation to $620 \mathrm{w} / \mathrm{cm}(19 \mathrm{kw} / \mathrm{ft})$. . . . . . 38

18. Fuel Centerline Temperature vs Burnup . . . . . . . . . . . 40

19. Change in Radial Fuel Temperature Distribution with Time (UNC 80, Pellet 9) . . . . . . . . . . . . . . 41

20. Change in Helium-Bonded Carbide, Radial Temperature Distribution with Time (UNC 80, Pellet 27) . . . . . . . . . . . 42

21. Type 316 Clad Adjacent to Fuel after Irradiation . . . . . . . . . . . 44

22. Vanadium Clad Adjacent to Fuel after Irradiation . . . . . . . . . 45

23. Vanadium $-20 \mathrm{w} / \mathrm{o}$ Titanium Clad after Irradiation . . . . . . . . 46 


\section{INTRODUCTION}

United Nuclear Corporation is developing solid solution uranium-plutonium monocarbide, (UPu)C, as a competitive LMFBR fuel. The major objective of the program is to develop mixed-carbide LMFBR fuel rods that will perform satisfactorily up to $100,000 \mathrm{Mwd} / \mathrm{T}$ at power levels of 10 to $40 \mathrm{kw} / \mathrm{ft}$. As the first part of the fast reactor irradiation program, three (UPu)C-fueled rods were irradiated in the EBR-II to a burnup of $10.6 \times 10^{20} \mathrm{fiss} / \mathrm{cm}^{3}(30,000 \mathrm{Mwd} / \mathrm{T})$.

The objectives of the pilot irradiation were:

1. To obtain fast flux irradiation results on three full-length, heliumbonded, high-density pellet carbide rods in a practical length of time, to the minimum significant burnup, and at a significant power.

a. Full-length rod irradiations (as opposed to short rods) give information on the stability of a long column of fuel and the interaction between fuel movement and cladding restraint.

b. The fast flux provides the prototypical environment for the fuel rod. This is significantly different from previous thermal flux irradiations.

2. To obtain irradiation experiment design and handling experience in EBR-II. 
The design and fabrication of these rods was reported in UNC-5137. ${ }^{1}$ This report covers the irradiation at EBR-II, operated by Argonne National Laboratory, and the post-irradiation examination at Battelle Memorial Institute, Columbus, Ohio. 


\section{SUMMARY AND CONCLUSIONS}

The three helium-bonded pilot rods fueled with high-density, hyperstoichiometric structure $\left(\mathrm{U}_{0.8} \mathrm{Pu}_{0.2}\right) \mathrm{C}$ pellets performed as designed during irradiation at the EBR-II. The rods operated up to a power of $28 \mathrm{kw} / \mathrm{ft}$ to a peak burnup of about $10.6 \times 10^{20}$ fiss $/ \mathrm{cm}^{3}(30,000 \mathrm{Mwd} / \mathrm{T})$ based on $\mathrm{Nd}^{148}$ and $\mathrm{U}-\mathrm{Pu}$ isotopic analyses. This is the highest power at which mixed carbides have been irradiated in a fast reactor.

The fuel and clad performance was excellent. Type 316 clad OD increase was zero within the accuracy of the measurement and a maximum possible of $0.11 \%$ per $10,000 \mathrm{Mwd} / \mathrm{T}$. The vanadium-type clad OD increases were a maximum of $0.25 \%$ per $10,000 \mathrm{Mwd} / \mathrm{T}$. Fuel structure was essentially unchanged except for fission gas porosity at the grain boundaries in the central region of the highest power pellets. There was no detectable plutonium or fission product migration by alpha or beta-gamma autoradiography. The average fuel density changes, as measured by immersion, were in the range of 1.4 to $1.8 \%$ per $10,000 \mathrm{Mwd} / \mathrm{T}$, similar to previous thermal irradiations. Fission gas release was a maximum of $0.5 \%$ of theoretical.

There were no reactions between the fuel and the type 316 stainless steel or vanadium clad and a slight reaction with the vanadium-20 w/o titanium. Clad sections from all rods were found to be ductile when bent at room temperature. 
The fuel rods performed as predicted in these experiments. The good correlation between predicted and actual clad strain is particularly gratifying. If the fuel continues to behave in this manner at higher burnups, helium-bonded, high-density pellets will be able to achieve $100,000 \mathrm{Mwd} / \mathrm{T}$ at 20 to $30 \mathrm{kw} / \mathrm{ft}$. 


\section{EXPERIMENT DESCRIPTION AND OPERATION}

The fuel rods are tubes with welded end plugs, 23-in. long, containing $\sim 14$ in. of $\left(\mathrm{U}_{0.8} \mathrm{Pu}_{0.2}\right) \mathrm{C}$ pellets. The pellets were fabricated by cold pressing and sintering $(\mathrm{UPu}) \mathrm{C}$ powder made by carbothermic reduction of the oxides. High densities, $96 \%$ of theoretical, were achieved by the use of $0.1 \mathrm{w} / \mathrm{o}$ nickel sintering aid. Pellet characterization is given in Table 1, and typical pellets are shown in Fig. 1. The rods were designated as UNC 78, 79, and 80, and were clad with vanadium $-20 \mathrm{w} / \mathrm{o}$ titanium, type 316 stainless steel, and vanadium, respectively. The design and fabrication of the rods were detailed in a previous

topical report. ${ }^{1}$ The vanadium and $\mathrm{V}-20 \mathrm{Ti}$ clad rods were designed for operation at a peak power of $985 \mathrm{w} / \mathrm{cm}$ while the stainless steel clad rod was designed for a peak power of $655 \mathrm{w} / \mathrm{cm}$. Fuel and rod dimensions are given in Table 2.

The rods were encapsulated in a standard ANL, type 304 stainless steel capsule with a thermal bond of sodium in the annulus between the fuel rod and the capsule. A typical cross-sectional view of a loaded capsule is shown in Fig. 2. After nondestructive tests including radiography for pellet and rod location and eddy current examination for rod-to-capsule sodium bond integrity, the capsules were sent to Argonne National Laboratory, Chicago, for assembly into a 19-rod EBR-II subassembly. At ANL, the rods were placed in Assembly X009 and irradiated for 5355 reactor Mwd or $2850 \mathrm{hr}$ in Row 4, Position 4A2, of the EBR-II. Burnup, power, and temperatures calculated from reactor data are given in Table 2 (and Table 9 of Section 4.2.5), and Figs. 3, 4, and 5. 

Sintered Density

\begin{tabular}{|c|c|c|c|c|c|c|c|c|c|c|}
\hline Rod & Diameter, in. & $\begin{array}{l}\text { By Dimensions } \\
\text { and Weight, } \\
\mathrm{g} / \mathrm{cm}^{3}\end{array}$ & $\begin{array}{c}\mathrm{By} \mathrm{CCl}_{4} \\
\text { Immersion, } \\
\mathrm{g} / \mathrm{cm}^{3} \\
\end{array}$ & $\begin{array}{c}\mathrm{C} \\
\mathrm{w} / \mathrm{o} \\
\end{array}$ & $\begin{array}{l}\mathrm{Pu}, \\
\mathrm{w} / \mathrm{o}\end{array}$ & $\begin{array}{l}\mathrm{N}, \\
\mathrm{ppm}\end{array}$ & $\begin{array}{c}\mathrm{O} \\
\underline{\mathrm{ppm}}\end{array}$ & $\begin{array}{l}\mathrm{Ni}, \\
\text { ppm }\end{array}$ & $\begin{array}{c}\text { Equivalent } \mathrm{C} \text {, } \\
\mathrm{w} / \mathrm{o}\end{array}$ & X-Ray Analysis (Diffractometer) \\
\hline 78 & $0.2512 \pm 0.0005$ & $13.23 \neq 0.03$ & $13.31 \pm 0.02$ & 4.81 & 18.9 & 300 & 3800 & 1400 & 4.92 & $\begin{array}{l}\text { Major (UPu)C type } \\
\mathrm{a}_{0}=4.9676 \pm 0.0011 \AA \\
\text { Faint/weak }(\mathrm{UPu})_{2} \mathrm{C}_{3} \text { type } \\
\text { Faint indication of }(\mathrm{UPu}) \mathrm{O}_{2} \text { type }\end{array}$ \\
\hline 79 & $0.2520 \pm 0.0008$ & $13.25 \pm 0.05$ & $13.52 \pm 0.02$ & 4.73 & 19.1 & 1155 & 4600 & 1400 & 5.18 & $\begin{array}{l}\text { Major }(\mathrm{UPu}) \mathrm{C} \text { type } \\
\mathrm{a}_{0}=4.9660 \pm 0.0005 \AA \\
\text { Weak }(\mathrm{UPu})_{2} \mathrm{C}_{3} \text { type }\end{array}$ \\
\hline 80 & $0.2509 \pm 0.0008$ & $13.18 \pm 0.10$ & $13.01 \pm 0.02$ & 4.78 & 19.2 & 300 & 3900 & 1400 & 5.10 & $\begin{array}{l}\text { Major }(\mathrm{UPu}) \mathrm{C} \text { type } \\
\mathrm{a}_{0}=4.967 \pm 0.0004 \AA \\
\text { Faint }(\mathrm{UPu})_{2} \mathrm{C}_{3} \text { type }\end{array}$ \\
\hline
\end{tabular}




\section{TABLE 2 - SUMMARY OF IRRADIATION CONDITI ONS}

\begin{tabular}{|c|c|c|c|}
\hline & UNC 78 & UNC 79 & UNC 80 \\
\hline Clad & $\mathrm{V}-20 \mathrm{Ti}$ & Type 316 & Vanadium \\
\hline Fuel & $\left(\mathrm{U}_{0.8} \mathrm{Pu}_{0.2}\right) \mathrm{C}$ & $\left(\mathrm{U}_{0.8} \mathrm{Pu}_{0.2}\right) \mathrm{C}$ & $\left(\mathrm{U}_{0.8} \mathrm{Pu}_{0.2}\right) \mathrm{C}$ \\
\hline Smear Density, \% T.D. & 94 & 93 & 93 \\
\hline Fuel OD, in. & 0.251 & 0.252 & 0.251 \\
\hline Fuel-Clad Gap Cold at Startup, diametral in. & 0.005 & 0.007 & 0.006 \\
\hline Clad Thickness, in. & 0.021 & 0.023 & 0.022 \\
\hline $\begin{array}{l}\text { Calculated Maximum Fuel Temperature at } \\
\text { Startup, }{ }^{\circ} \mathrm{C}\end{array}$ & 1505 & 1465 & 1595 \\
\hline Calculated Clad Surface Temperature, ${ }^{\circ} \mathrm{C}$ & 630 & 600 & 630 \\
\hline Design Maximum Clad Strain, $\%$ & 0.4 & 0.0 & 0.4 \\
\hline Maximum Linear Power, w/cm & 920 & 625 & 920 \\
\hline Maximum Clad Surface Heat Flux, w/ $\mathrm{cm}^{2}$ & 385 & 255 & 385 \\
\hline Maximum Fuel Power Density: & & & \\
\hline $\mathrm{kw} / \mathrm{cm}^{3}$ & 2.90 & 1.95 & 2.90 \\
\hline $\mathrm{w} / \mathrm{g}(\mathrm{U}+\mathrm{Pu})$ & 230 & 155 & 230 \\
\hline $\operatorname{Max} \int^{\mathrm{T}_{\mathrm{c}}} \mathrm{kd} \theta, \mathrm{w} / \mathrm{cm}$ & 73.0 & 49.5 & 73.0 \\
\hline Time at Power, hr & 2850 & 2850 & 2850 \\
\hline Clad Exposure, nvt & $1.7 \times 10^{22}$ & $1.7 \times 10^{22}$ & $1.7 \times 10^{22}$ \\
\hline $\begin{array}{l}\text { Burnup Peak: } \\
\text { fiss } / \mathrm{cm}^{3} \\
\text { (Mwd } / \mathrm{T} \text { ) }\end{array}$ & $\begin{array}{l}10.2 \times 10^{20} \\
(29,000)\end{array}$ & $\begin{array}{l}7.4 \times 10^{20} \\
(21,000)\end{array}$ & $\begin{array}{l}10.6 \times 10^{20} \\
(30,000)\end{array}$ \\
\hline
\end{tabular}




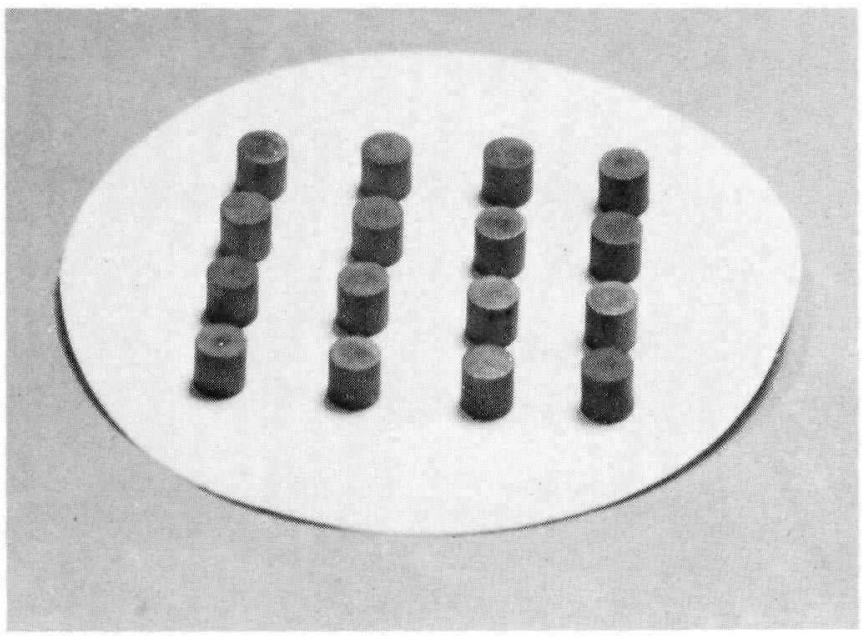

Some of the pellets used for UNC 79

Fig. 1 - Typical $\left(\mathrm{U}_{0.8} \mathrm{Pu}_{0.2}\right) \mathrm{C}$ Fuel Pellets 


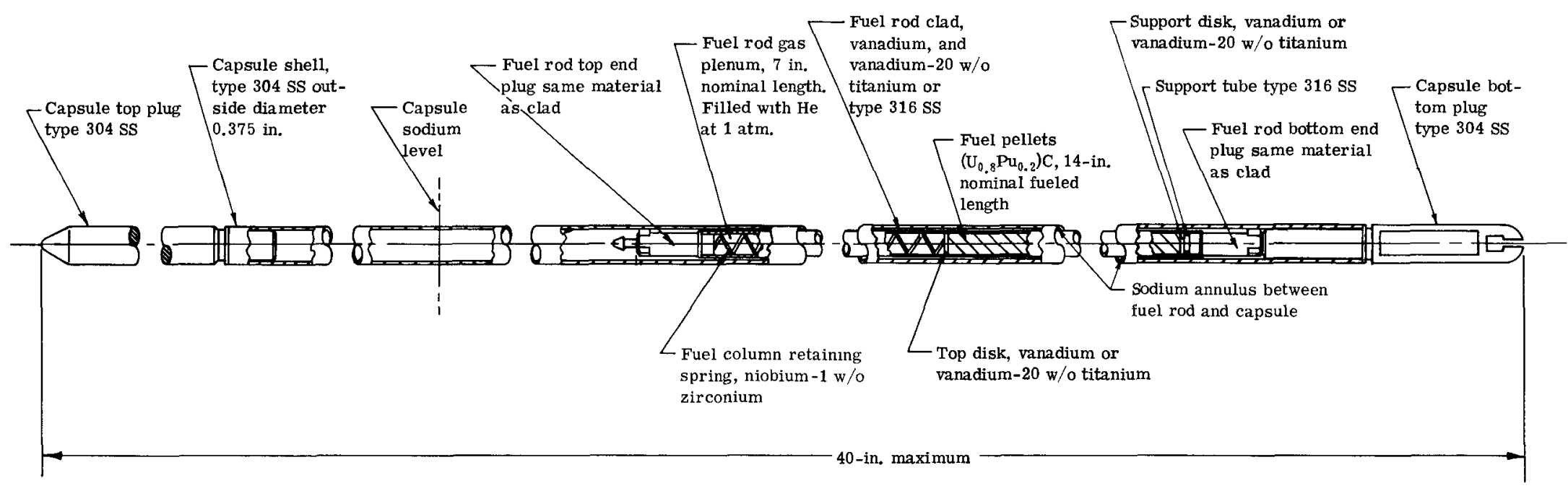

Fig. 2 - Cross -Sectional View of Typical EBR-II Irradiation Capsule Assembly 

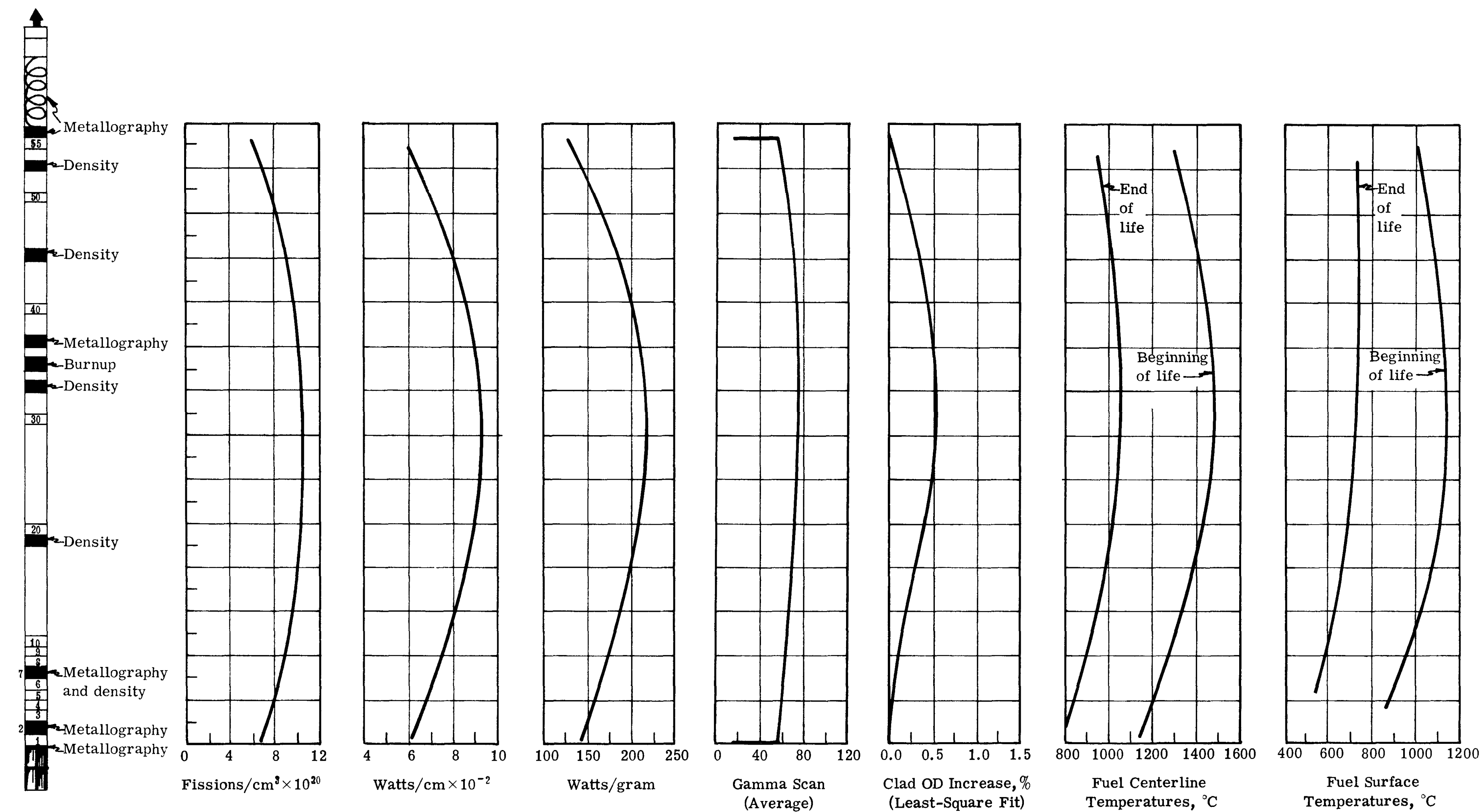

Fig. 3 - UNC 78 Performance Summary 

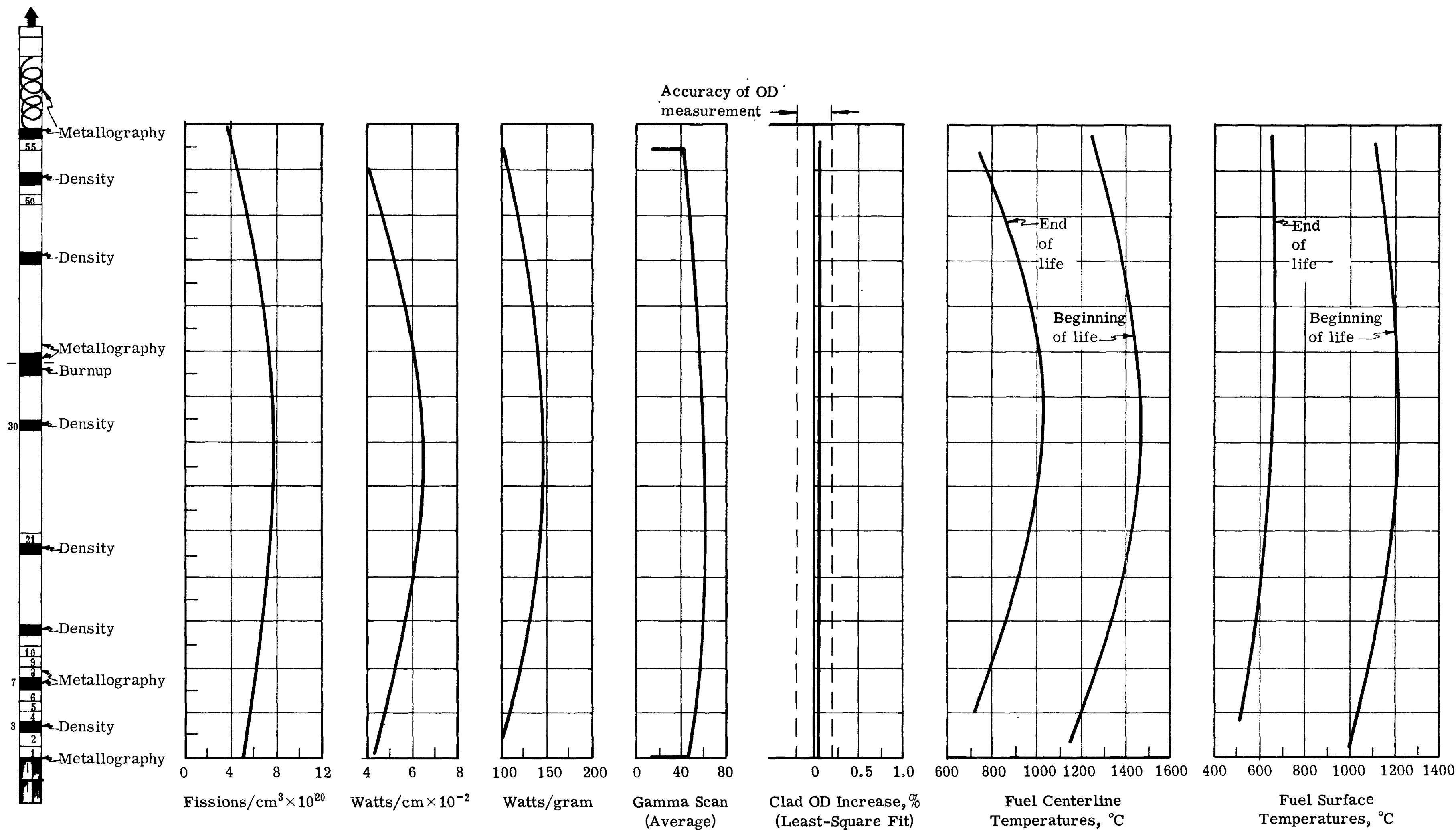

Fig. 4-UNC 79 Performance Summary 

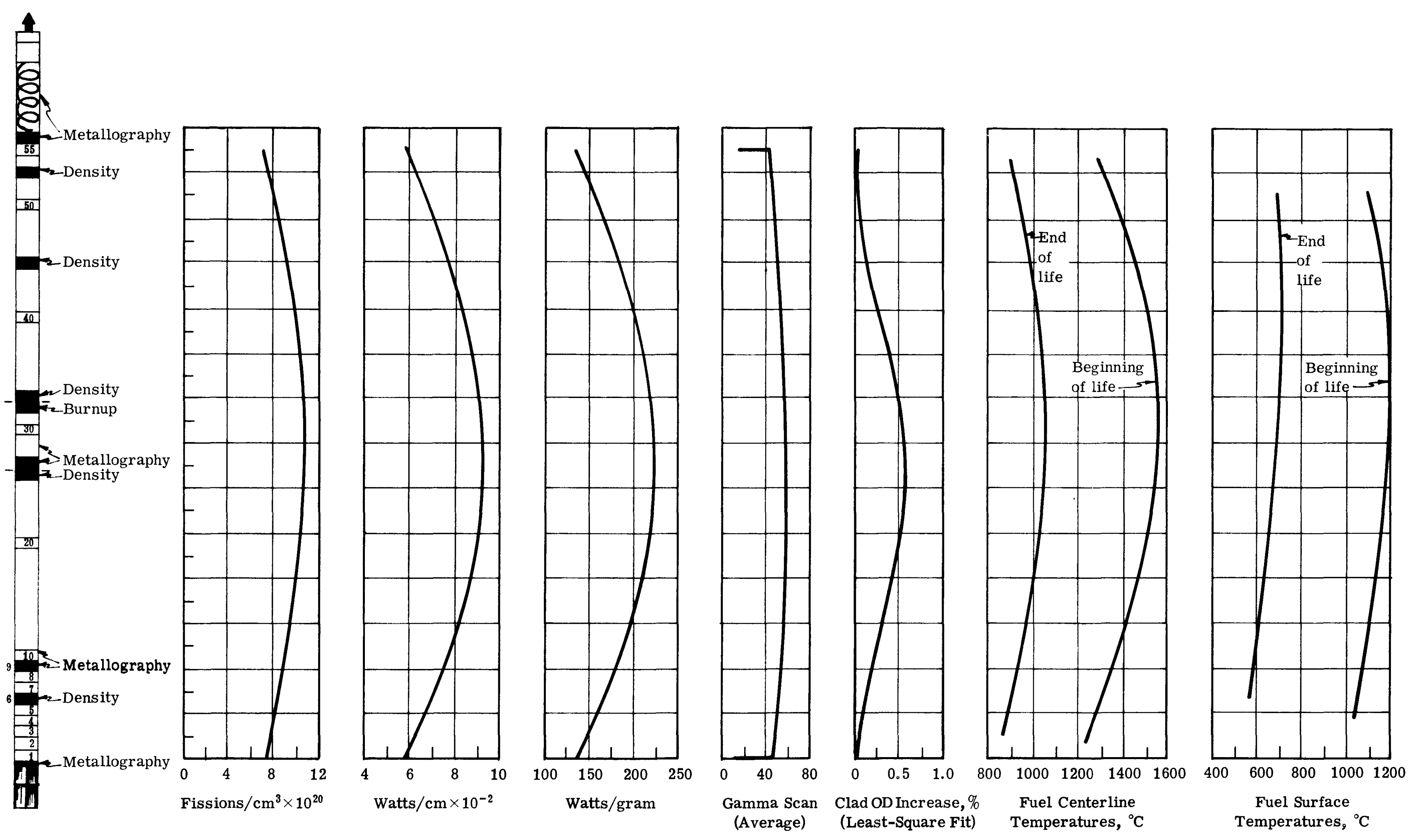

Fig. 5 - UNC 80 Performance Summary 
The relative positions of the UNC rods in the subassembly are shown in Fig. 6. Vibratory compacted and low-density pellet fuel was irradiated by ANL in positions 8,12 , and 16 of this subassembly in cladding from the same lot of tubing as the UNC rods. The results will offer a good performance comparison between the different types of fuel. 


\section{As Loaded}

\begin{tabular}{|c|c|c|c|}
\hline Position & $\begin{array}{c}\text { Capsule } \\
\text { Type }\end{array}$ & $\begin{array}{c}\text { Ident. } \\
\text { No. }\end{array}$ & Comments \\
\hline 1 & ANL & AS-27 & Structural material \\
\hline 2 & GE & $\mathrm{L} 4 \mathrm{C}$ & Structural material \\
\hline 3 & ANL & SP-13 & Cermet fuel \\
\hline 4 & BNWL & $\mathrm{A} 1$ & Structural material \\
\hline 5 & ANL & SOV -6 & Oxide fuel \\
\hline 6 & UNC & UNC -80 & Carbide fuel \\
\hline 7 & UNC & UNC -79 & Carbide fuel \\
\hline 8 & ANL & SMV -1 & Carbide fuel \\
\hline 9 & BNWL & A5 & Structural material \\
\hline 10 & ANL & AS-14 & Structural material \\
\hline 11 & ANL & $5 P-14$ & Cermet fuel \\
\hline 12 & ANL & VMV -1 & Carbide fuel \\
\hline 13 & ANL & SOV -5 & Oxide fuel \\
\hline 14 & BNWL & $\mathrm{A} 2$ & Structural material \\
\hline 15 & ANL & AS-15 & Structural material \\
\hline 16 & ANL & SMP-1 & Carbide fuel \\
\hline 17 & GE & $\mathrm{L} 4 \mathrm{D}$ & Structural material \\
\hline 18 & BNWL & A6 & Structural material \\
\hline 19 & UNC & UNC - 78 & Carbide fuel \\
\hline
\end{tabular}

Subassembly No. Internal orifice diameter For core location

X009

0.750 in. $4 \mathrm{~A} 2$

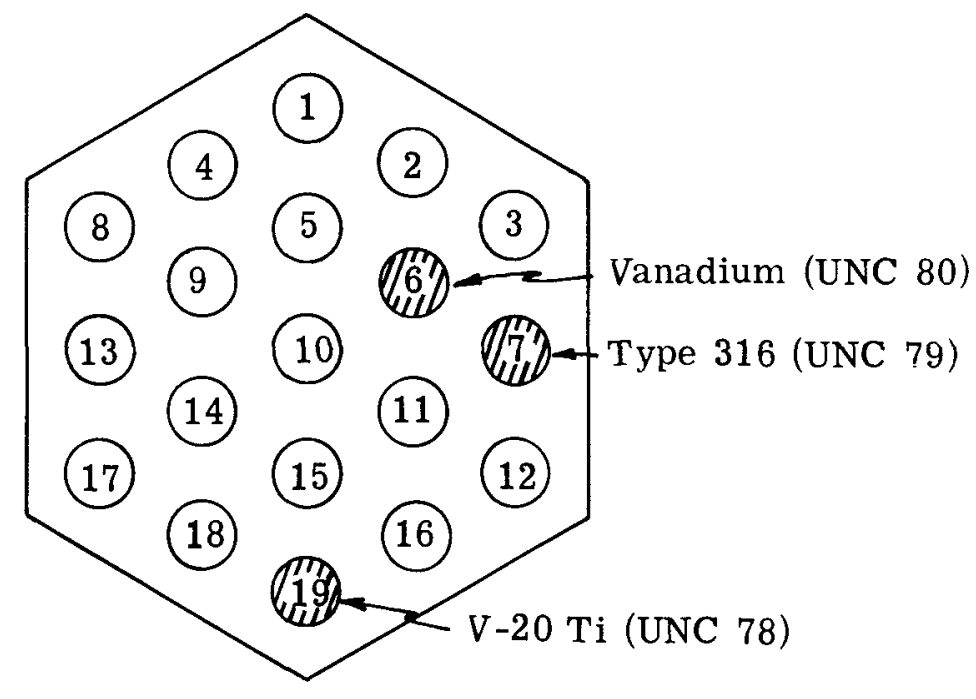

View looking down on T-bar grid

Fig. 6 - Positions of UNC Rods in EBR-II Subassembly 


\section{POST-IRRADIATION EXAMINATION}

The fuel rods were shipped from EBR-II after about three months of cooling time to Battelle Memorial Institute, Columbus, Ohio, for post-irradiation examination. The examination included the determination of:

- Fuel and clad dimensional stability

- Fuel location by gamma scanning

- Fission gas release

- Metallography of fuel and clad structure

- Burnup determination

- Plutonium and fission product distribution

- Fuel oxygen content

- Clad hardness and ductility.

The results of the examination are given in detail in the following sections and are summarized in Table 3.

Additional examinations will be carried out by other AEC-sponsored programs on samples supplied by United Nuclear from these fuel rods:

Hot burst tests on the clad gas plenum section BMI, Columbus

Electron microscopy and gas analysis of the clad ORNL

Electron microscopy and microprobe analysis of the fuel

ANL

Reprocessing studies on the fuel ORNL. 
TABLE 3 - SUMMARY OF POST-IRRADIATION EXAMINATION RESULTS

\begin{tabular}{|c|c|c|c|}
\hline & UNC 78 & UNC 79 & UNC 80 \\
\hline Clad Material & $\mathrm{V}-20 \mathrm{Ti}$ & Type 316 & Vanadium \\
\hline Clad Appearance & Excellent & Excellent & Excellent \\
\hline Clad Integrity & $\begin{array}{l}\text { Intact except } \\
\text { one thin } \\
\text { crack near } \\
\text { weld }\end{array}$ & Intact & Intact \\
\hline $\begin{array}{l}\text { Fission Gas Release, \% of } \\
\text { theoretical }\end{array}$ & 0.20 & 0.36 & 0.50 \\
\hline Condition of Pellets & $\begin{array}{l}\text { Most pellets } \\
\text { recovered } \\
\text { whole, some } \\
\text { sodium oxide } \\
\text { on surface }\end{array}$ & $\begin{array}{l}\text { Surface excel- } \\
\text { lent, all pel- } \\
\text { lets cracked }\end{array}$ & $\begin{array}{l}\text { Surface excel- } \\
\text { lent, all pel- } \\
\text { lets cracked }\end{array}$ \\
\hline $\begin{array}{l}\text { Clad OD Increase: } \\
\text { Average, } \% \\
\% / 10,000 \mathrm{Mwd} / \mathrm{T}\end{array}$ & $\begin{array}{l}0.4 \\
0.15\end{array}$ & $\begin{array}{l}0.1 \\
0.07\end{array}$ & $\begin{array}{l}0.4 \\
0.15\end{array}$ \\
\hline $\begin{array}{l}\text { Pellet OD Increase: } \\
\text { Average, } \% \\
\% / 10,000 \mathrm{Mwd} / \mathrm{T}\end{array}$ & $\begin{array}{l}2.5 \\
0.9\end{array}$ & - & - \\
\hline $\begin{array}{l}\text { Fuel Density Decrease by } \\
\text { Immersion: } \\
\text { Average, } \% \\
\% / 10,000 \mathrm{Mwd} / \mathrm{T}\end{array}$ & $\begin{array}{l}4.1 \\
1.6\end{array}$ & $\begin{array}{l}3.3 \\
1.8\end{array}$ & $\begin{array}{l}4.0 \\
1.4\end{array}$ \\
\hline Fuel Metallography & As before, but & th fission gas bu & bles at pellet centers \\
\hline Clad Metallography & $\begin{array}{l}\text { Reaction op- } \\
\text { posite fueled } \\
\text { region }\end{array}$ & $\begin{array}{l}\text { No fuel-clad } \\
\text { reaction }\end{array}$ & $\begin{array}{l}\text { No fuel-clad } \\
\text { reaction }\end{array}$ \\
\hline Clad Bend Test & Ductile & Ductile & Ductile \\
\hline $\begin{array}{l}\text { Plutonium and Fission } \\
\text { Product Distribution }\end{array}$ & Uniform & Uniform & Uniform \\
\hline
\end{tabular}




\subsection{FUEL ROD PERFORMANCE}

\subsubsection{Visual Examination}

The fuel rods were removed from the capsules and examined. The surfaces of all the rods were excellent. The rods were intact except for a thin crack near the weld of the bottom end plug in UNC 78, the V-20 Ti clad rod (Fig. 7). The crack was sufficiently small to prevent significant fission gas leakage to the capsule. All the rods were rolled on a granite block to obtain a rough measurement of bowing which could possibly be due to the thermal gradient. UNC 78 was fairly straight while UNC 79 and UNC 80 were slightly bowed. With handling, the bow of the stainless clad rod, UNC 79, increased to a value of about 0.015 to 0.030 in.

\subsubsection{Clad Measurement}

The outside diameters of the rods were measured every inch in two planes, the second 90 degrees from the first. The rods were placed in a V-shaped tray and readings were taken with a micrometer. The diameter values obtained are given in Tables 4, 5, and 6 together with the calculated percent change in diameter. The average percent changes or strains are plotted with the calculated design strains in Fig. 8. The experimental values are in agreement with the design values of clad strain within the uncertainty of the measurements.

The percent change in diameter was plotted as a function of length in the fuel region and compared to the burnup-power profile in Figs. 3, 4, and 5. The shape of the curves for UNC 78 and $80(\mathrm{~V} \mathrm{clad}, 28 \mathrm{kw} / \mathrm{ft})$ follows the shape of the burnup, power, and gamma scan curves indicating greater clad strain at the higher performance levels. The maximum clad strain was $0.8 \%$ or $0.25 \% / 10,000 \mathrm{Mwd} / \mathrm{T}$.

The data for UNC 79 (type $316,19 \mathrm{kw} / \mathrm{ft}$ ) give a flat curve indicating nearly zero change within the accuracy of the measurements. The maximum possible clad strain was $0.2 \%$ or $0.11 \% / 10,000 \mathrm{Mwd} / \mathrm{T}$. 


\section{TABLE 4 - POST-IRRADIATION CLAD DIAMETER MEASUREMENTS OF UNC 78* (V-20 Ti CLAD) \\ (Pre-Irradiation Diameter -0.2990 in.)}

\begin{tabular}{|c|c|c|c|c|c|c|}
\hline & $\begin{array}{l}\text { Axial } \\
\text { Position } \dagger\end{array}$ & $\begin{array}{c}\text { Diameter at } \\
\text { Punch Mark, } \\
\text { in. } \\
\end{array}$ & $\begin{array}{c}\text { Diameter } 90^{\circ} \\
\text { from Mark, } \\
\text { in. } \\
\end{array}$ & $\begin{array}{c}\text { Average } \\
\text { Diameter, } \\
\text { in. } \\
\end{array}$ & $\begin{array}{c}\text { Change } \\
\text { (Strain), } \\
\text { in. } \\
\end{array}$ & $\begin{array}{c}\text { Change } \\
\text { (Strain), } \\
\% \\
\end{array}$ \\
\hline \multirow{9}{*}{$\Xi$} & 10 & 0.2984 & 0.2986 & 0.2985 & 0 & 0 \\
\hline & 1 & 0.2987 & 0.2985 & 0.2986 & 0 & 0 \\
\hline & 2 & 0.2986 & 0.2986 & 0.2986 & 0 & 0 \\
\hline & 3 & 0.2988 & 0.2989 & 0.2989 & 0 & 0 \\
\hline & 4 & 0.2984 & 0.2987 & 0.2986 & 0 & 0 \\
\hline & 5 & 0.2985 & 0.2987 & 0.2986 & 0 & 0 \\
\hline & 6 & 0.2985 & 0.2988 & 0.2987 & 0 & 0 \\
\hline & 7 & 0.2987 & 0.2990 & 0.2989 & 0 & 0 \\
\hline & 8 & 0.2988 & 0.2994 & 0.2991 & 0 & 0 \\
\hline \multirow{12}{*}{ 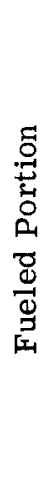 } & 9 & 0.2994 & 0.2998 & 0.2996 & 0.0006 & 0.2 \\
\hline & 10 & 0.2995 & 0.2998 & 0.2997 & 0.0007 & 0.2 \\
\hline & 11 & 0.2997 & 0.3000 & 0.2999 & 0.0009 & 0.3 \\
\hline & 12 & 0.3000 & 0.3002 & 0.3001 & 0.0011 & 0.4 \\
\hline & 13 & 0.3002 & 0.3004 & 0.3003 & 0.0013 & 0.4 \\
\hline & 14 & 0.3008 & 0.3005 & 0.3007 & 0.0017 & 0.6 \\
\hline & 15 & 0.3007 & 0.3006 & 0.3007 & 0.0017 & 0.6 \\
\hline & 16 & 0.3005 & 0.3004 & 0.3005 & 0.0015 & 0.5 \\
\hline & 17 & 0.3006 & 0.3002 & 0.3004 & 0.0014 & 0.5 \\
\hline & 18 & 0.2998 & 0.2998 & 0.2998 & 0.0008 & 0.3 \\
\hline & 19 & 0.2996 & 0.2997 & 0.2997 & 0.0007 & 0.2 \\
\hline & 20 & 0.2993 & 0.2995 & 0.2994 & 0.0004 & 0.1 \\
\hline
\end{tabular}

*Post-irradiation diameters are accurate to within \pm 0.0005 in.

$\dagger$ Axial positions start at the top of the fuel rod and are approximately 1 -in. apart. 
TABLE 5 - POST -IRRADIATION CLAD DIAMETER MEASUREMENTS OF UNC 79* (TYPE 316 CLAD)

(Pre-Irradiation Diameter -0.3060 in.)

\begin{tabular}{|c|c|c|c|c|c|c|}
\hline & $\begin{array}{c}\text { Axial } \\
\text { Position } \dagger \\
\end{array}$ & $\begin{array}{l}\text { Diameter at } \\
\text { Punch Mark, } \\
\text { in. } \\
\end{array}$ & $\begin{array}{c}\text { Diameter } 90^{\circ} \\
\text { from Mark, } \\
\text { in. } \\
\end{array}$ & $\begin{array}{c}\text { Average } \\
\text { Diameter, } \\
\text { in. } \\
\end{array}$ & $\begin{array}{c}\text { Change } \\
\text { (Strain), } \\
\text { in. } \\
\end{array}$ & $\begin{array}{c}\text { Change } \\
\text { (Strain), } \\
\% \\
\end{array}$ \\
\hline & 0 & 0.3069 & 0.3063 & 0.3066 & 0.0006 & 0.2 \\
\hline & 1 & 0.3060 & 0.3059 & 0.3060 & 0 & 0 \\
\hline & 2 & 0.3061 & 0.3063 & 0.3062 & 0 & 0 \\
\hline & 3 & 0.3060 & 0.3060 & 0.3060 & 0 & 0 \\
\hline & 4 & 0.3060 & 0.3060 & 0.3060 & 0 & 0 \\
\hline & 5 & 0.3062 & 0.3064 & 0.3063 & 0 & 0 \\
\hline & 6 & 0.3059 & 0.3060 & 0.3060 & 0 & 0 \\
\hline & 7 & 0.3061 & 0.3061 & 0.3061 & 0 & 0 \\
\hline & 8 & 0.3059 & 0.3062 & 0.3061 & 0 & 0 \\
\hline \multirow{14}{*}{ 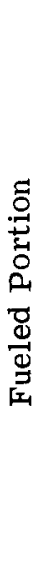 } & 9 & 0.3063 & 0.3059 & 0.3061 & 0 & 0 \\
\hline & 10 & 0.3062 & 0.3059 & 0.3061 & 0 & 0 \\
\hline & 11 & 0.3064 & 0.3064 & 0.3064 & 0.0004 & 0.1 \\
\hline & 12 & 0.3066 & 0.3060 & 0.3063 & 0 & 0 \\
\hline & 13 & 0.3063 & 0.3063 & 0.3063 & 0 & 0 \\
\hline & 14 & 0.3065 & 0.3063 & 0.3064 & 0.0004 & 0.1 \\
\hline & 15 & 0.3065 & 0.3061 & 0.3063 & 0 & 0 \\
\hline & 16 & 0.3063 & 0.3061 & 0.3061 & 0 & 0 \\
\hline & 17 & 0.3060 & 0.3062 & 0.3061 & 0 & 0 \\
\hline & 18 & 0.3067 & 0.3064 & 0.3066 & 0.0006 & 0.2 \\
\hline & 19 & 0.3069 & 0.3064 & 0.3067 & 0.0007 & 0.2 \\
\hline & 20 & 0.3068 & 0.3066 & 0.3067 & 0.0007 & 0.2 \\
\hline & 21 & 0.3065 & 0.3069 & 0.3067 & 0.0007 & 0.2 \\
\hline & 22 & 0.3068 & 0.3064 & 0.3066 & 0.0006 & 0.2 \\
\hline
\end{tabular}

*Post-irradiation diameters are accurate to within \pm 0.0005 in.

†Axial positions start at the top of the fuel rod and are approximately $1-\mathrm{in}$. apart. 


\section{TABLE 6 - POST-IRRADIATION CLAD DIAMETER MEASUREMENTS OF UNC 80* (V CLAD) \\ (Pre-Irradiation Diameter -0.3007 in.)}

\begin{tabular}{|c|c|c|c|c|c|}
\hline $\begin{array}{c}\text { Axial } \\
\text { Position } \dagger\end{array}$ & $\begin{array}{l}\text { Diameter at } \\
\text { Punch Mark, } \\
\text { in. } \\
\end{array}$ & $\begin{array}{l}\text { Diameter } 90^{\circ} \\
\text { from Mark, } \\
\text { in. } \\
\end{array}$ & $\begin{array}{c}\text { Average } \\
\text { Diameter, } \\
\text { in. } \\
\end{array}$ & $\begin{array}{c}\text { Change } \\
\text { (Strain), } \\
\text { in. } \\
\end{array}$ & $\begin{array}{c}\text { Change } \\
\text { (Strain), } \\
\%\end{array}$ \\
\hline 0 & 0.3003 & 0.3001 & 0.3002 & 0 & 0 \\
\hline 1 & 0.3004 & 0.3003 & 0.3004 & 0 & 0 \\
\hline 2 & 0.3005 & 0.3007 & 0.3006 & 0 & 0 \\
\hline 3 & 0.3007 & 0.3008 & 0.3008 & 0 & 0 \\
\hline 4 & 0.3007 & 0.3009 & 0.3008 & 0 & 0 \\
\hline 5 & 0.3009 & 0.3009 & 0.3009 & 0 & 0 \\
\hline 6 & 0.3010 & 0.3008 & 0.3009 & 0 & 0 \\
\hline 7 & 0.3009 & 0.3010 & 0.3010 & 0 & 0 \\
\hline 8 & 0.3008 & 0.3006 & 0.3007 & 0 & 0 \\
\hline 9 & 0.3014 & 0.3008 & 0.3011 & 0.0004 & 0.1 \\
\hline 10 & 0.3011 & 0.3010 & 0.3011 & 0.0004 & 0.1 \\
\hline 11 & 0.3020 & 0.3013 & 0.3017 & 0.0010 & 0.3 \\
\hline 12 & 0.3022 & 0.3020 & 0.3021 & 0.0014 & 0.5 \\
\hline 13 & 0.3020 & 0.3020 & 0.3020 & 0.0013 & 0.4 \\
\hline 14 & 0.3027 & 0.3025 & 0.3026 & 0.0019 & 0.6 \\
\hline 15 & 0.3028 & 0.3024 & 0.3026 & 0.0019 & 0.6 \\
\hline 16 & 0.3032 & 0.3028 & 0.3030 & 0.0023 & 0.8 \\
\hline 17 & 0.3027 & 0.3025 & 0.3026 & 0.0019 & 0.6 \\
\hline 18 & 0.3021 & 0.3030 & 0.3026 & 0.0019 & 0.6 \\
\hline 19 & 0.3011 & 0.3020 & 0.3016 & 0.0009 & 0.3 \\
\hline 20 & 0.3008 & 0.3012 & 0.3010 & 0 & 0 \\
\hline 21 & 0.3009 & 0.3009 & 0.3009 & 0 & 0 \\
\hline
\end{tabular}

*Post-irradiation diameters are accurate to within \pm 0.0005 in.

$\dagger$ Axial positions start at the top of the fuel rod and are approximately 1 -in. apart. 


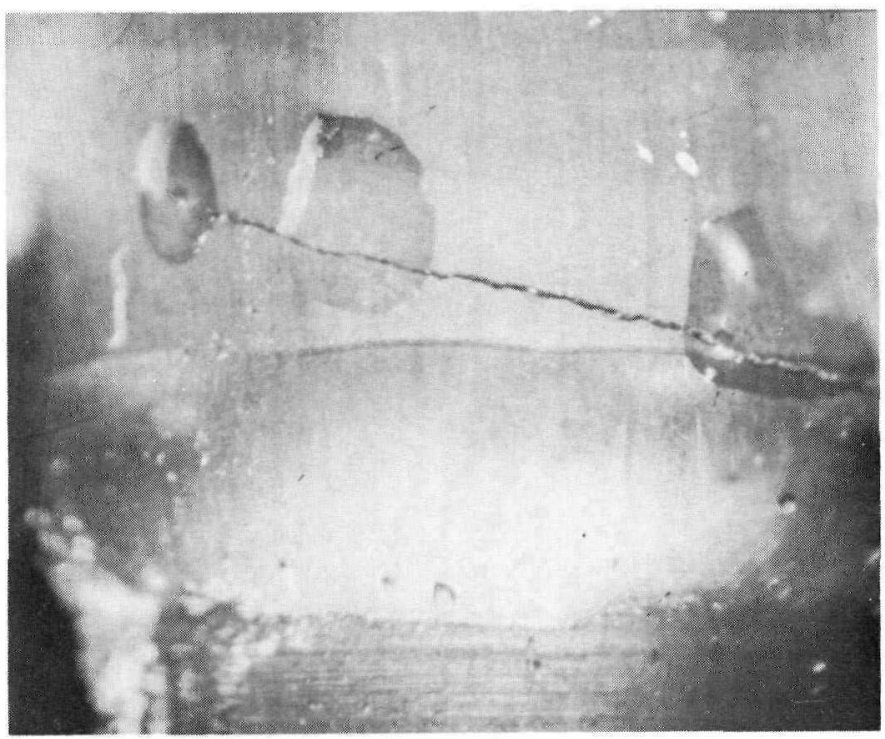

$12 \times$

Fig. 7 - Thin Crack near UNC 78 Bottom End Plug Weld 


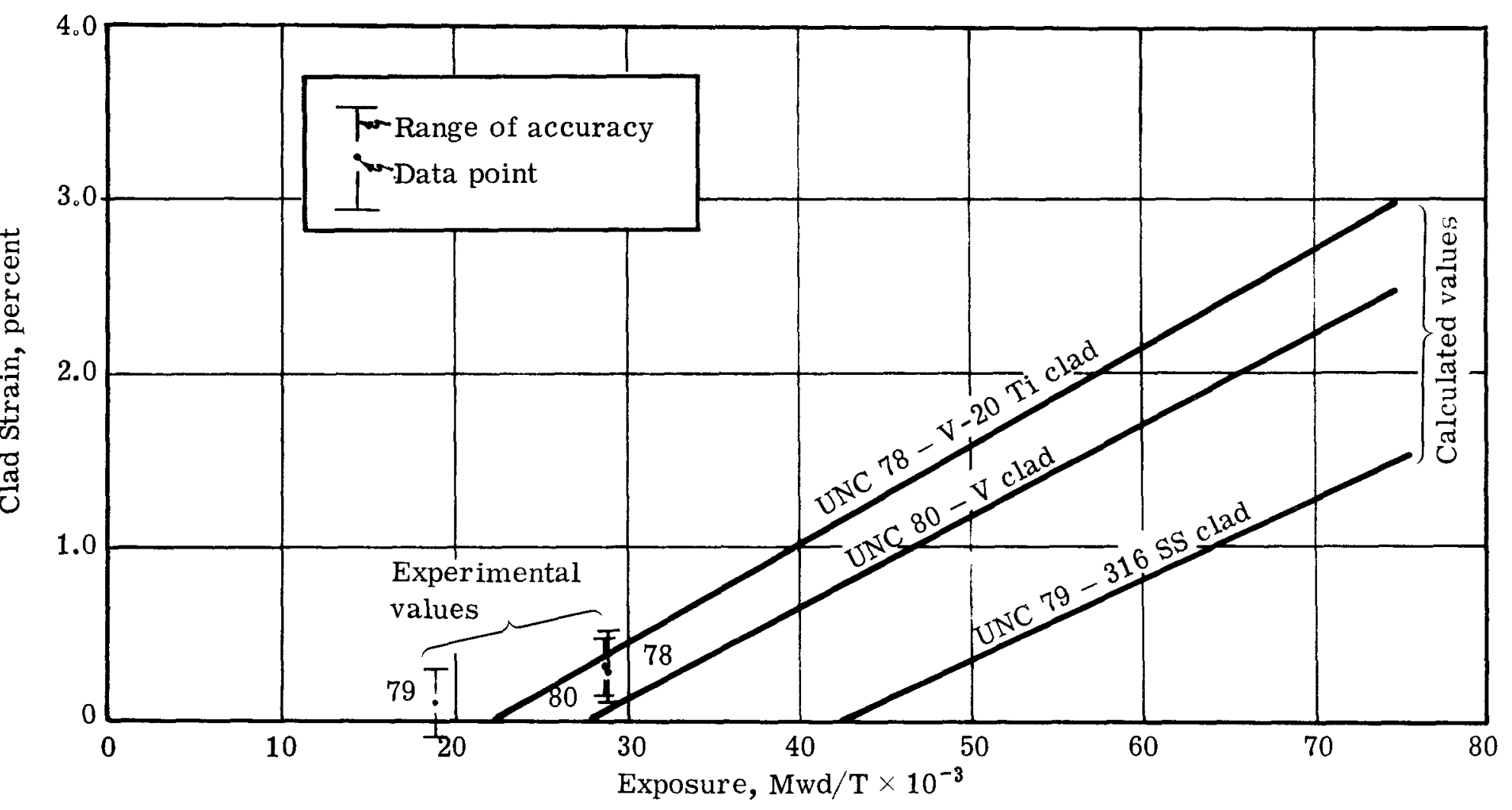

Fig. 8 - Comparison of Calculated and Actual Clad Strain vs Burnup 
The percent change per $10,000 \mathrm{Mwd} / \mathrm{T}$ for peak and average values of burnup is summarized in Table 7.

\subsubsection{Gamma Scanning}

Gamma scans of all three rods were similar in appearance. Gamma plots are shown in Figs. 3, 4, and 5. The gamma scans for the capsules were similar to the scans for the associated rods. Gamma activity increased from the top of the fuel column to the fuel midplane and then decreased slowly on approaching the bottom of the fuel column. The sharp localized dips in gamma activity are probably due to small pellet separations. These separations are probably caused by mechanical movement during transfer operations since no pellet-pellet interactions were found.

Changes in fuel column length were determined from the gamma scan since the scan is accurate to within \pm 0.01 in. The results of these measurements, which are given below, show no appreciable length change.

\begin{tabular}{|c|c|c|c|}
\hline \multirow[b]{2}{*}{ UNC Rod } & \multicolumn{2}{|c|}{ Fuel Column Length, in. } & \multirow{2}{*}{$\begin{array}{c}\text { Fuel Column } \\
\text { Length } \\
\text { Increase, \% }\end{array}$} \\
\hline & Pre-Ir radiation & Post-Irradiation & \\
\hline 78 & 14.090 & 14.088 & 0.0 \\
\hline 79 & 14.130 & 14.163 & +0.2 \\
\hline 80 & 14.310 & 14.288 & -0.2 \\
\hline
\end{tabular}

\subsubsection{Fission Gas Release}

Fission gases were removed from all rods and analyzed by mass spectrometer. Based on average burnup values, the fission gas release was found to be as follows: 
TABLE 7 - SUMMARY OF CLAD DIAMETER CHANGES

\begin{tabular}{|c|c|c|c|c|c|c|}
\hline Clad & Value & $\begin{array}{l}\text { Pre- } \\
\text { Irradiation, } \\
\text { in. }\end{array}$ & $\begin{array}{l}\text { Post- } \\
\text { Irradiation, } \\
\text { in. }\end{array}$ & $\begin{array}{l}\text { Change, } \\
\text { in. }\end{array}$ & $\begin{array}{c}\% \\
\text { Change }\end{array}$ & $\begin{array}{l}\% \text { Change per } \\
10,000 \mathrm{Mwd} / \mathrm{T}\end{array}$ \\
\hline \multirow[t]{2}{*}{$\mathrm{V}-20 \mathrm{Ti}$} & Average & 0.2990 & 0.3001 & 0.0011 & 0.37 & 0.15 \\
\hline & Peak & 0.2990 & 0.3007 & 0.0017 & 0.57 & 0.20 \\
\hline \multirow[t]{2}{*}{ Type 316} & Average & 0.3060 & 0.3064 & 0.0004 & 0.13 & 0.07 \\
\hline & Peak & 0.3060 & 0.3067 & 0.0007 & 0.23 & 0.11 \\
\hline \multirow[t]{2}{*}{ Vanadium } & Average & 0.3007 & 0.3019 & 0.0012 & 0.40 & 0.15 \\
\hline & Peak & 0.3007 & 0.3030 & 0.0023 & 0.76 & 0.25 \\
\hline
\end{tabular}




$\begin{array}{cc}\begin{array}{c}\text { Fuel } \\ \text { Rod }\end{array} & \begin{array}{c}\text { Fission Gas } \\ \text { Release, \% }\end{array} \\ 78 & 0.20 \\ 79 & 0.36 \\ 80 & 0.50\end{array}$

A small quantity of fission gas $(<0.01 \%$ of that produced based on gamma spectrometric analysis for $\mathrm{Kr}^{85}$, the minimum detectable by mass spectrometer) was found in the outer capsule shell of UNC 78. This gas probably leaked through the crack in the bottom end plug weld of the fuel rod. No fission gases were found in the capsule shells of UNC 79 and 80.

\subsection{FUEL PER FORMANCE}

\subsubsection{Visual Examination}

The clad was slit longitudinally in three planes approximately $120^{\circ}$ apart, and the clad was peeled back as shown in Fig. 9. In all cases, the cuts extended into the fuel, as shown in Fig. 10, and some damage to the pellets resulted. Whole pellets were obtained only from UNC 78. A typical group is shown in Fig. 11.

The appearance of the fuel pieces from UNC 79 and 80 was excellent, as shown in Fig. 12. Pellets from these rods contained one or two longitudinal "S-shaped" cracks prior to slitting as evidenced by replicas on the internal clad surfaces. Similar cracks were noted in the pellets from UNC 78 but these pellets did not fall apart during slitting. The surfaces of pellets from UNC 78 were covered with sodium oxide from sodium which leaked through the crack in the bottom end plug weld.

\subsubsection{Dimensional Changes}

The physical dimensions and weights were determined for the 30 whole pellets taken from UNC 78. The post-irradiation weights were within $1 \%$ of the pre- 


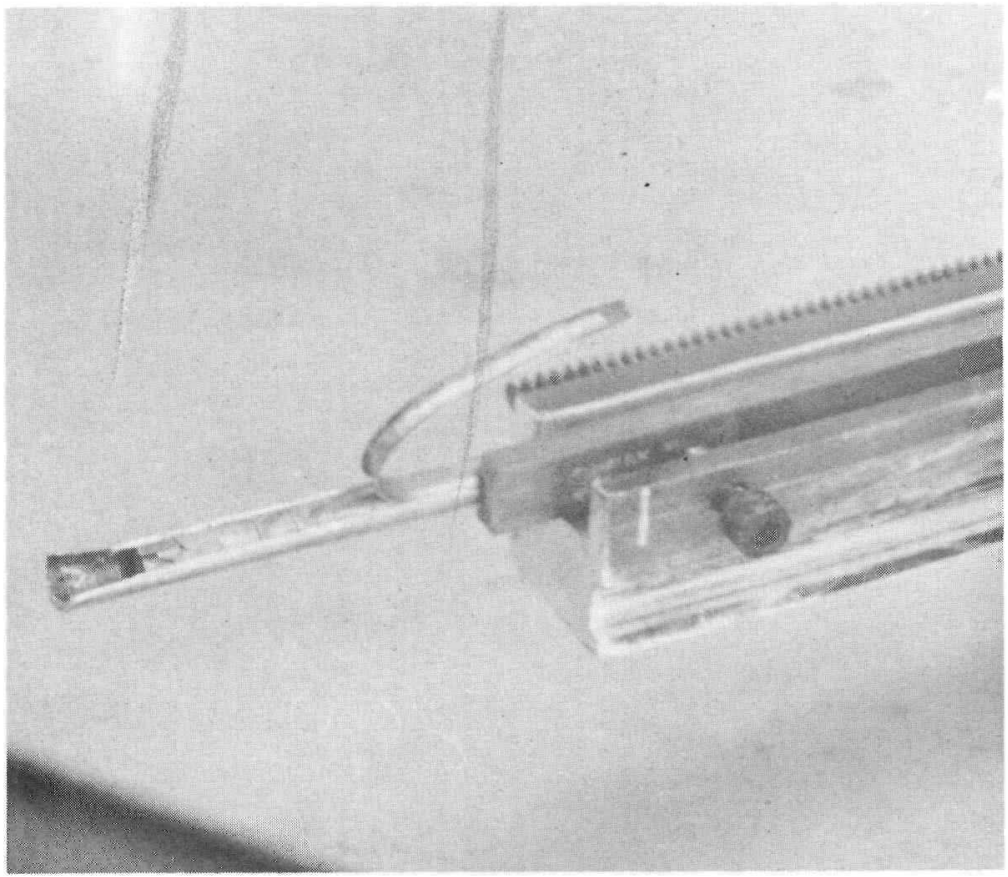

Fig. 9 - UNC 79 during Decladding (Note Type 316 Clad Ductility)

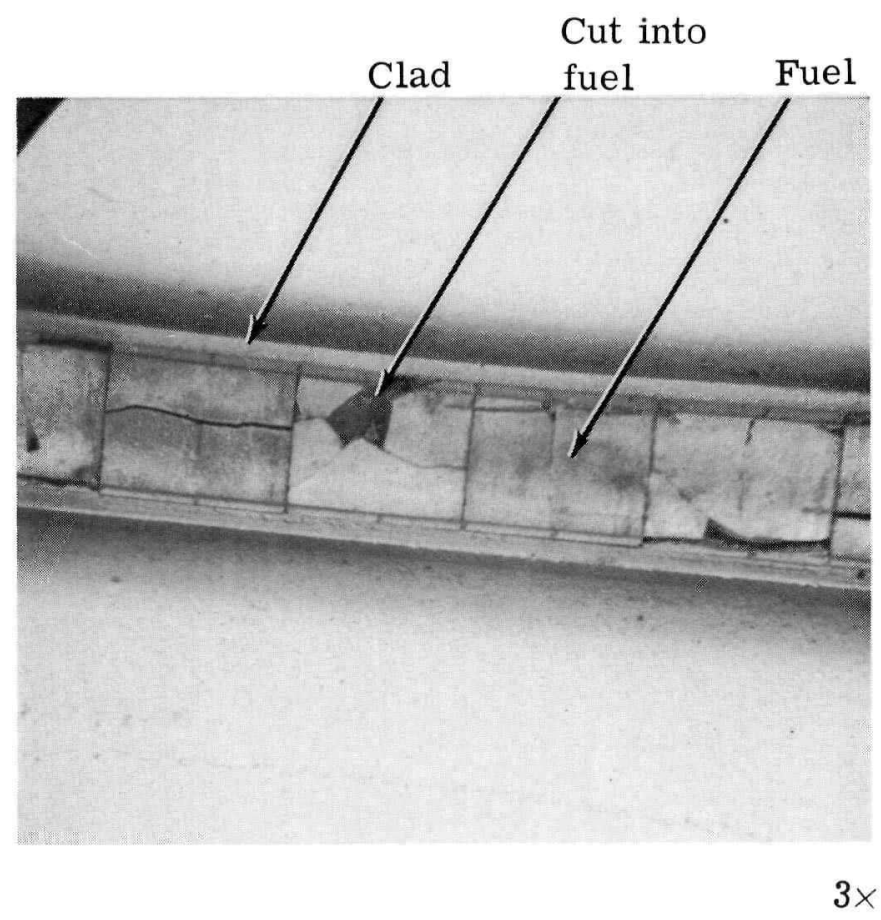

Fig. 10 - UNC 80 Partially Declad [(UPu)C Pellets in Vanadium Clad] 


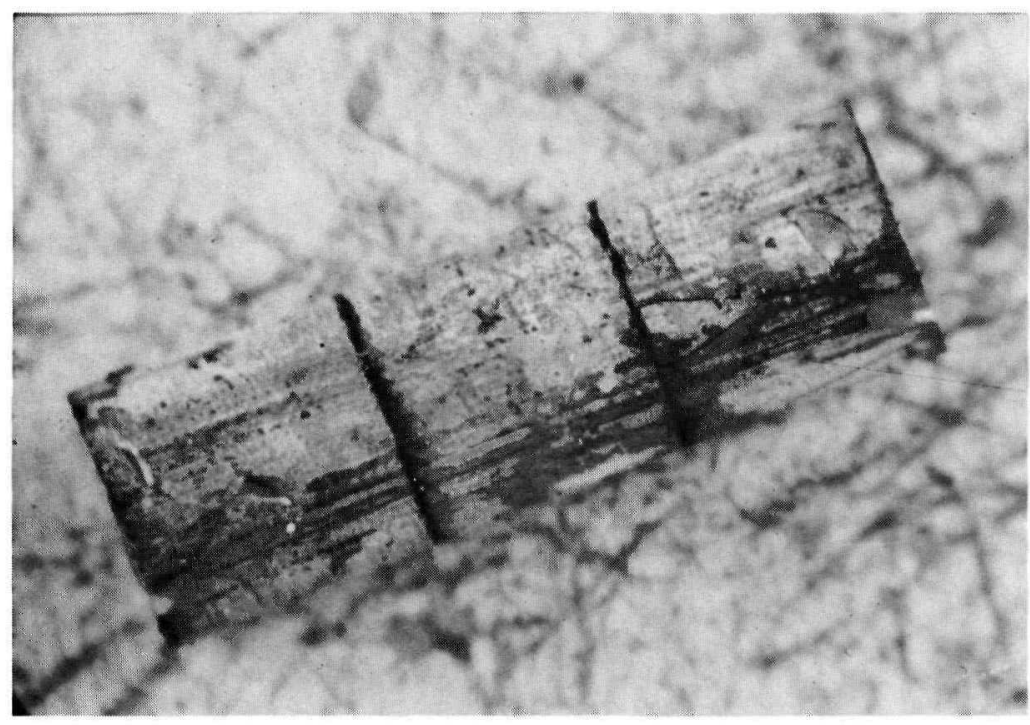

Fig. 11 - Whole Pellets from UNC 78 (V-20 Ti Claä) 


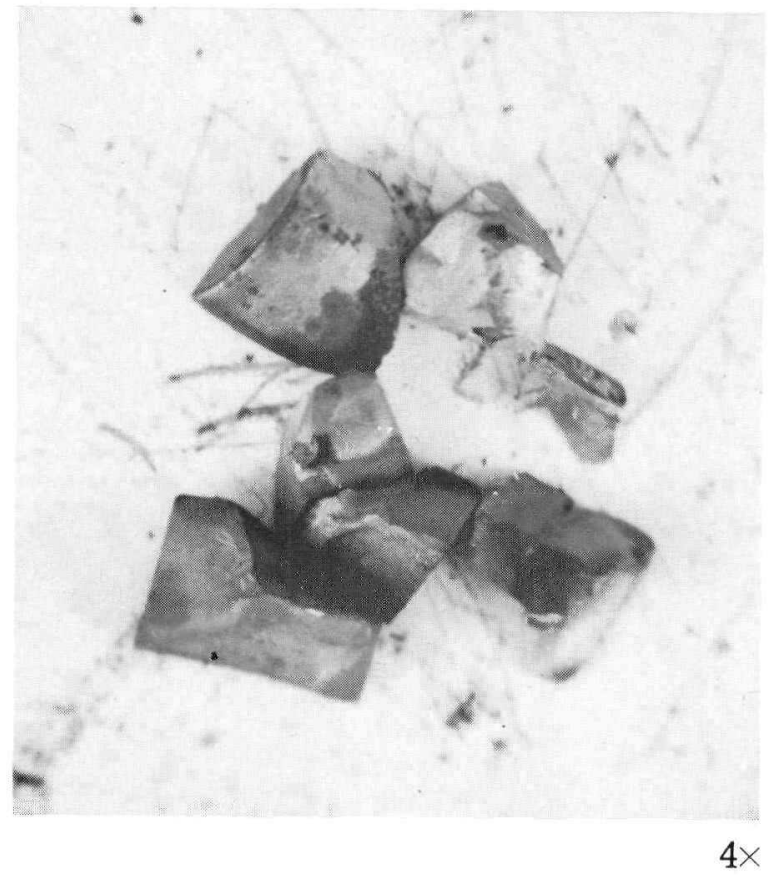

Fig. 12 - Typical Broken Fuel Pellet from UNC 79 (Type 316 Clad) 
irradiation weights, with most values $(85 \%)$ lying within $0.5 \%$ of the pre-irradiation weights. Pre-irradiation weights are accurate to $\pm 0.4 \%$ while post-irradiation weights are accurate to $\pm 0.1 \%$, so that the changes were within experimental error. Diameter values varied randomly and bore no relation to flux profile. The diameter increases were greater than would be expected from clad measurements. This discrepancy is due to a widening of the cracks in the pellets either from relief of the clad restraint or by the reaction of sodium in the cracks with the atmosphere.

For these reasons, the densities measured by immersion technique are probably a better assessment of swelling than are the dimension and weight measurements. The values are given in Table 8 along with relative volume change with burnup, $\Delta \mathrm{V} / \mathrm{V}$ per $10,000 \mathrm{Mwd} / \mathrm{T}$. The maximum specific volume change for fuel from both UNC 78 and 80 , the higher power $(28 \mathrm{kw} / \mathrm{ft})$ rods, was $2.0 \%$ per $10,000 \mathrm{Mwd} / \mathrm{T}$ with an average of 1.6 and $1.4 \%$, respectively. The maximum and average fuel volume changes for UNC 79, the lower power $(19 \mathrm{kw} / \mathrm{ft})$ rod, was 2.2 and $1.8 \%$ per $10,000 \mathrm{Mwd} / \mathrm{T}$, respectively.

\subsubsection{Structure}

Fuel pellets or portions of pellets were taken from the high and low power positions of all rods, as shown in Figs. 3, 4, and 5, and mounted for metallographic examination. All specimens were examined in the unetched as well as etched condition.

The outer portions of the pellets were as before irradiation. Burnup did not increase the porosity. There was no central void formation; however, porosity due to fission gas agglomeration was found in the central portions of the pellets. The amount of porosity increased with temperature. Fig. 13 shows the typical distribution of voids at the edges and centers of pellets taken from various power positions in the rods. The pores tend to agglomerate at grain boundaries, as previously noted in the thermal irradiations. ${ }^{2}$ 


\section{TABLE 8 - IMMERSION DENSITIES OF PELLETS}

\begin{tabular}{|c|c|c|c|c|c|}
\hline \multirow[b]{2}{*}{$\begin{array}{l}\text { UNC } \\
\text { Rod }\end{array}$} & \multirow[b]{2}{*}{$\begin{array}{c}\text { Pellet } \\
\text { No. } \\
\end{array}$} & \multicolumn{2}{|c|}{ Density, $\mathrm{g} / \mathrm{cm}^{3}$} & \multirow[b]{2}{*}{$\begin{array}{c}\text { Density } \\
\text { Change, \% } \\
\end{array}$} & \multirow[b]{2}{*}{$\begin{array}{c}\% \Delta V / V \text { per } \\
10,000 \mathrm{Mwd} / \mathrm{T}^{*}\end{array}$} \\
\hline & & $\begin{array}{c}\text { Pre- } \\
\text { Irradiation }\end{array}$ & $\begin{array}{c}\text { Post- } \\
\text { Irradiation }\end{array}$ & & \\
\hline \multirow[t]{5}{*}{78} & 7 & 13.10 & 12.73 & -2.8 & 1.2 \\
\hline & 19 & 13.26 & 12.58 & -5.1 & 1.8 \\
\hline & 33 & 13.26 & 12.49 & -5.8 & 2.0 \\
\hline & 45 & 13.22 & 12.69 & -4.0 & 1.6 \\
\hline & 53 & 13.20 & 12.80 & -3.0 & 1.5 \\
\hline \multirow[t]{6}{*}{79} & 3 & 13.26 & 12.96 & -2.3 & 1.6 \\
\hline & 12 & 13.22 & 12.90 & -2.4 & 1.4 \\
\hline & 20 & 13.27 & 12.76 & -3.8 & 1.9 \\
\hline & 30 & 13.27 & 12.64 & -4.8 & 2.2 \\
\hline & 45 & 13.25 & 12.75 & -3.8 & 2.2 \\
\hline & 52 & 13.25 & 12.85 & -3.0 & 2.2 \\
\hline \multirow[t]{5}{*}{80} & 6 & 13.05 & 12.69 & -2.8 & 1.2 \\
\hline & $25 \dagger$ & 13.11 & 12.31 & -6.1 & 2.0 \\
\hline & 33 & 13.12 & 12.37 & -5.7 & 1.9 \\
\hline & 45 & 13.14 & 12.70 & -3.4 & 1.3 \\
\hline & 53 & 13.14 & 12.85 & -2.2 & 10 \\
\hline
\end{tabular}

*Corrected for burnup profile in the rod.

$\dagger$ Probable pellet number from pellet group. 

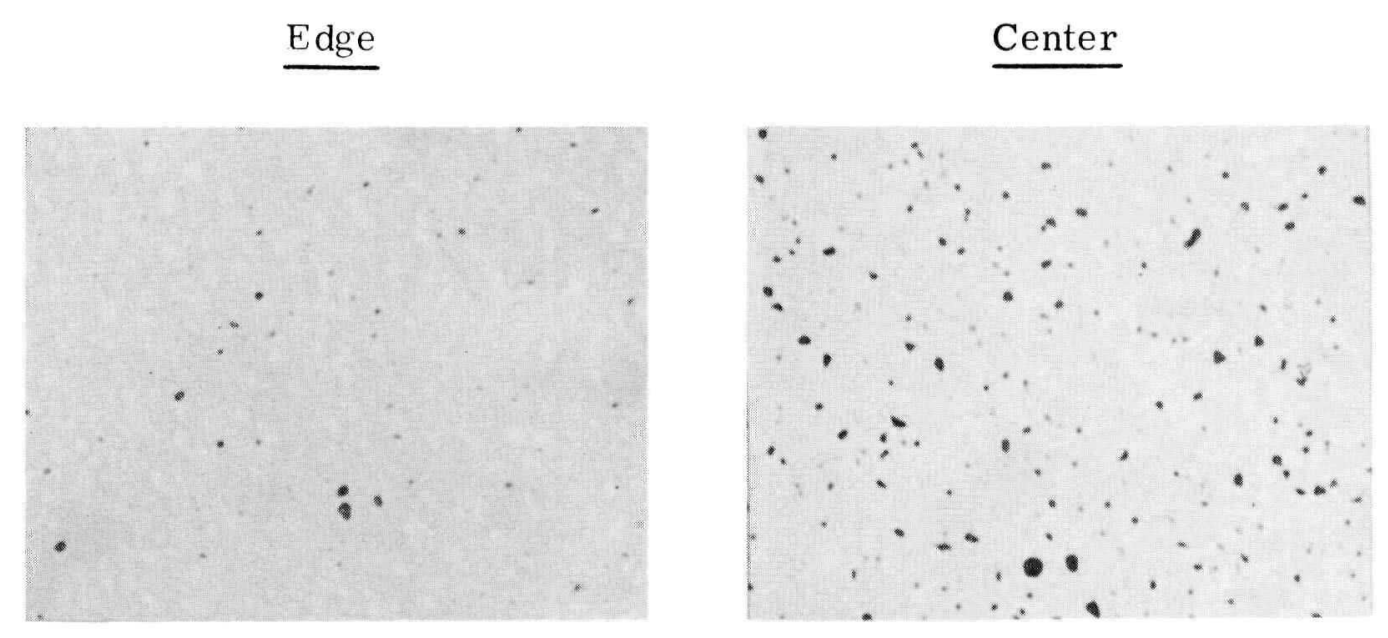

Pellet 7, UNC 78: $720 \mathrm{w} / \mathrm{cm}, 22,800 \mathrm{Mwd} / \mathrm{T}$
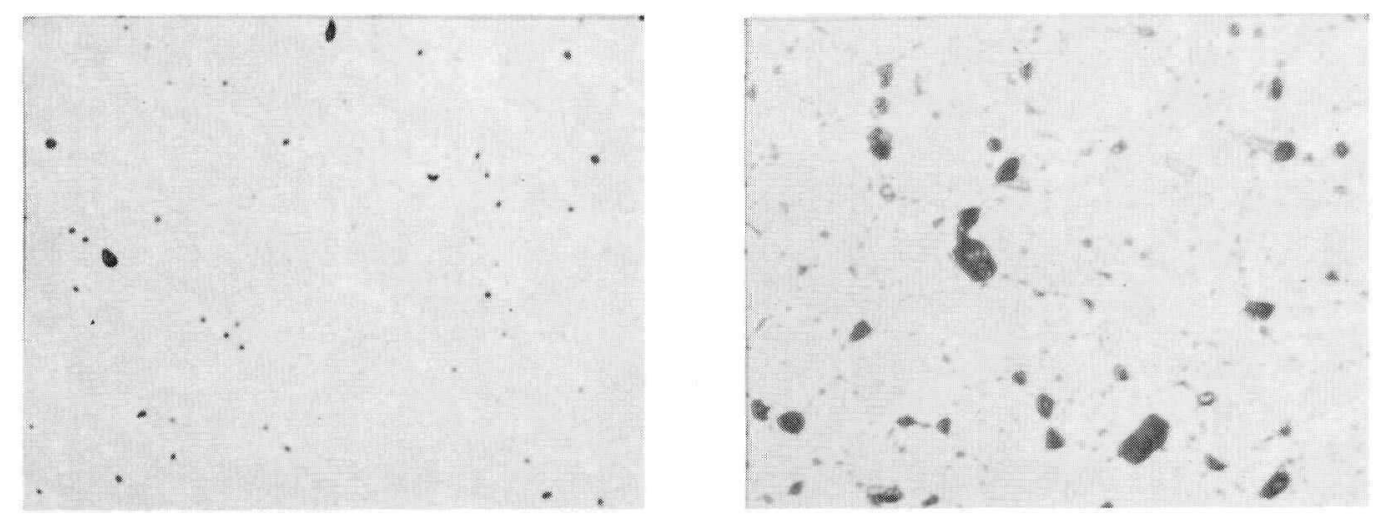

Pellet 35, UNC 79: $610 \mathrm{w} / \mathrm{cm}, 20,600 \mathrm{Mwd} / \mathrm{T}$
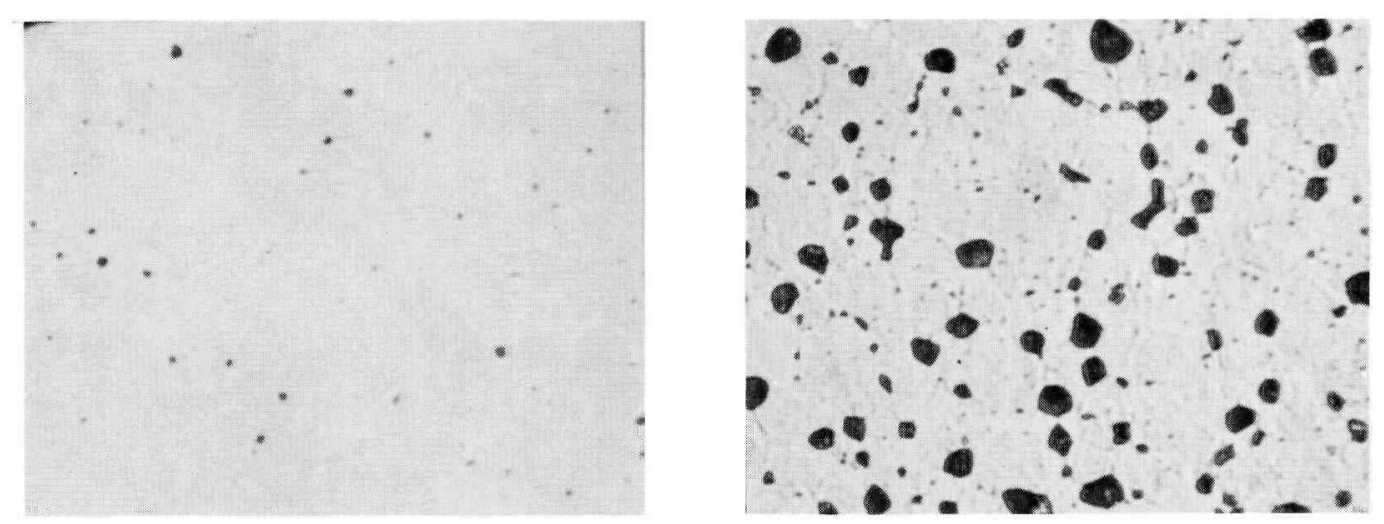

Pellet 27, UNC 80: $920 \mathrm{w} / \mathrm{cm}, 30,000 \mathrm{Mwd} / \mathrm{T}$

Fig. 13 - Typical Void Distribution in Fuel Pellets (Fuel Unetched, 500x) 
The fuel specimens were etched with the standard nitric-acetic-water mixture. No grain growth was present in any of the samples. The structure in the cooler outer two-thirds of the fuel pellets was unchanged from the pre-irradiation $(\mathrm{UPu}) \mathrm{C}+15 \mathrm{v} / \mathrm{o}(\mathrm{UPu})_{2} \mathrm{C}_{3}$ structure. At the center of the pellets, which operated at $720 \mathrm{w} / \mathrm{cm}$ and below, the structure was unchanged. At $760 \mathrm{w} / \mathrm{cm}$ and above, the sesquicarbide phase disappeared. Typical structures are shown in Figs. 14, 15 , and 16.

The mechanism for sesquicarbide disappearance is not known. In no case was there evidence of carbon migration to the outer pellet regions, fuel migration, or sesquicarbide decomposition to monocarbide plus dicarbide. The sesquicarbide disappearance is probably connected with a relatively small stoichiometry change induced by nickel or oxygen migration. It also may be connected with a higher fissioning rate in the sesquicarbide, based on microprobe investigator's reports of a higher plutonium concentration in the $\mathrm{M}_{2} \mathrm{C}_{3}$ than the $\mathrm{MC}$ phase.

Oxygen analysis by vacuum fusion on a high burnup pellet gave inconclusive results. The hot cell vacuum fusion rig gave a value of $\sim 400 \mathrm{ppm}$ for the irradiated pellet compared to $550 \mathrm{ppm}$ for the unirradiated control sample. Since (UPu)C pellets with less than $2000 \mathrm{ppm}$ oxygen had never been made at the time this lot of fuel was fabricated, the analyses are considered unreliable.

\subsubsection{Plutonium and Fission Product Distribution}

The specimens mounted for metallographic examination were used for the determination of plutonium and fission product distribution by alpha and beta autoradiography. Included were the samples from high and low power positions of all rods.

The intensity of all films was uniform. Therefore, no detectable segregation of plutonium or fission products occurred during the irradiation. Typical 


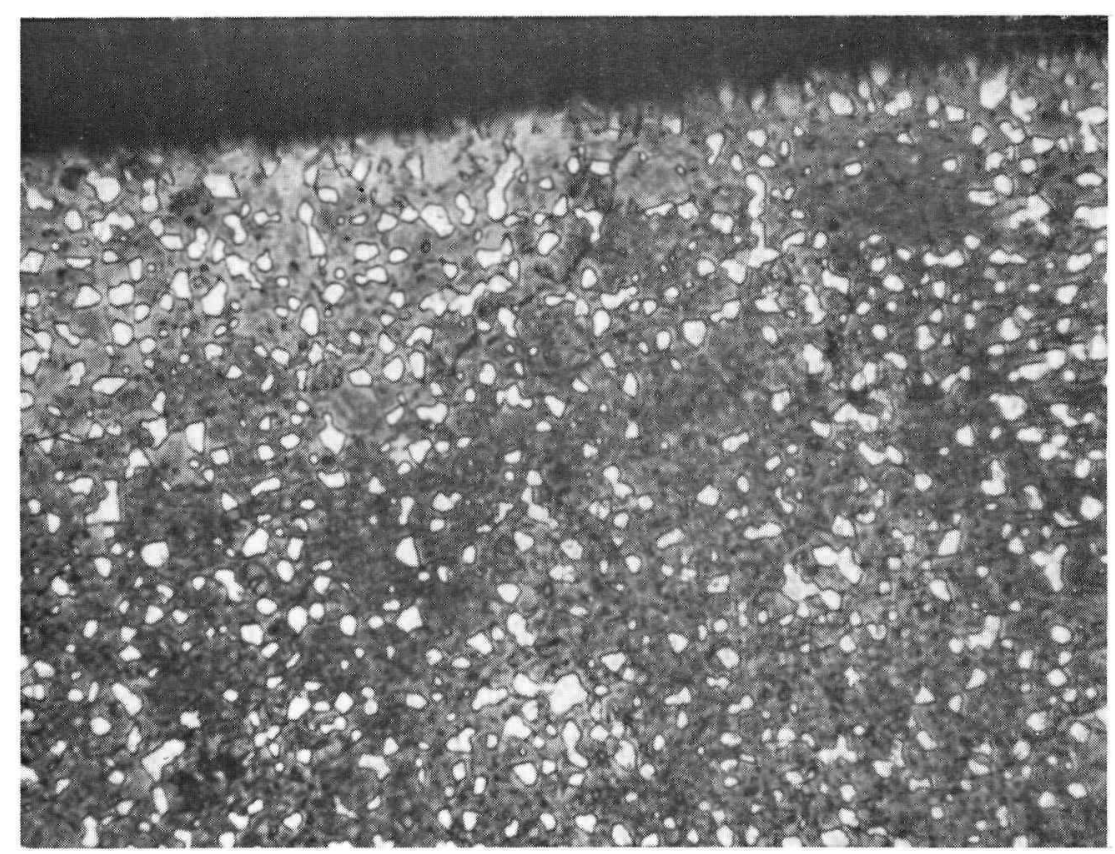

Pellet Edge

$500 \times$

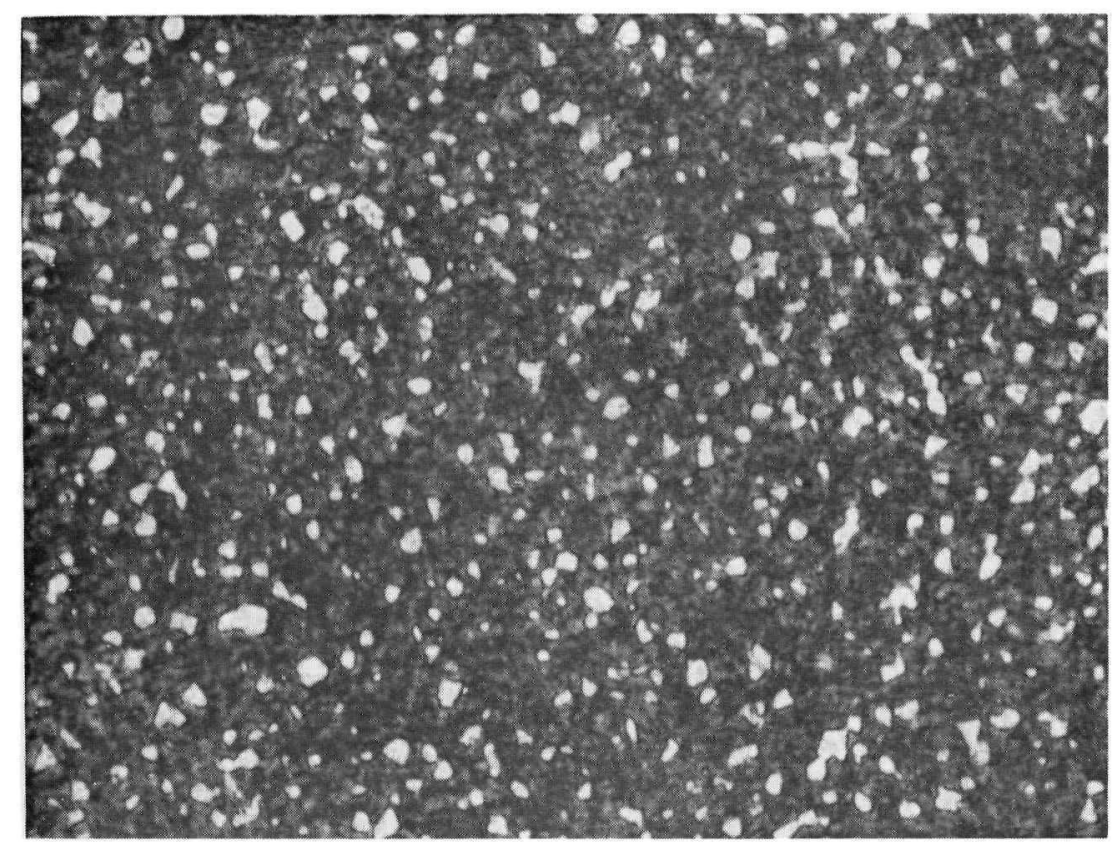

Pellet Center

$500 \times$

$(\mathrm{UPu}) \mathrm{C}$ is gray matrix, $(\mathrm{UPu})_{2} \mathrm{C}_{3}$ is white phase

Fig. 14 - Typical Fuel Structure (UNC 78, Pellet 7) after Ir radiation to: $720 \mathrm{w} / \mathrm{cm}(22 \mathrm{kw} / \mathrm{ft})$

$170 \mathrm{w} / \mathrm{g}$

$22,800 \mathrm{Mwd} / \mathrm{T}$ 


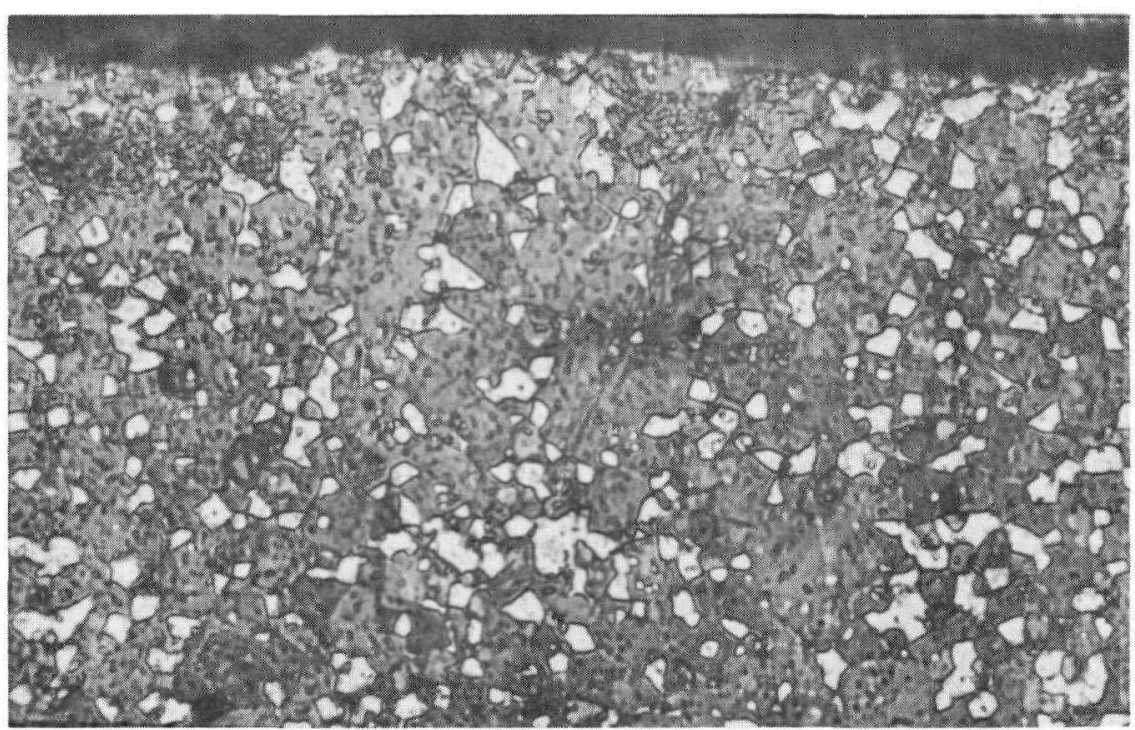

Pellet Edge

$500 \times$

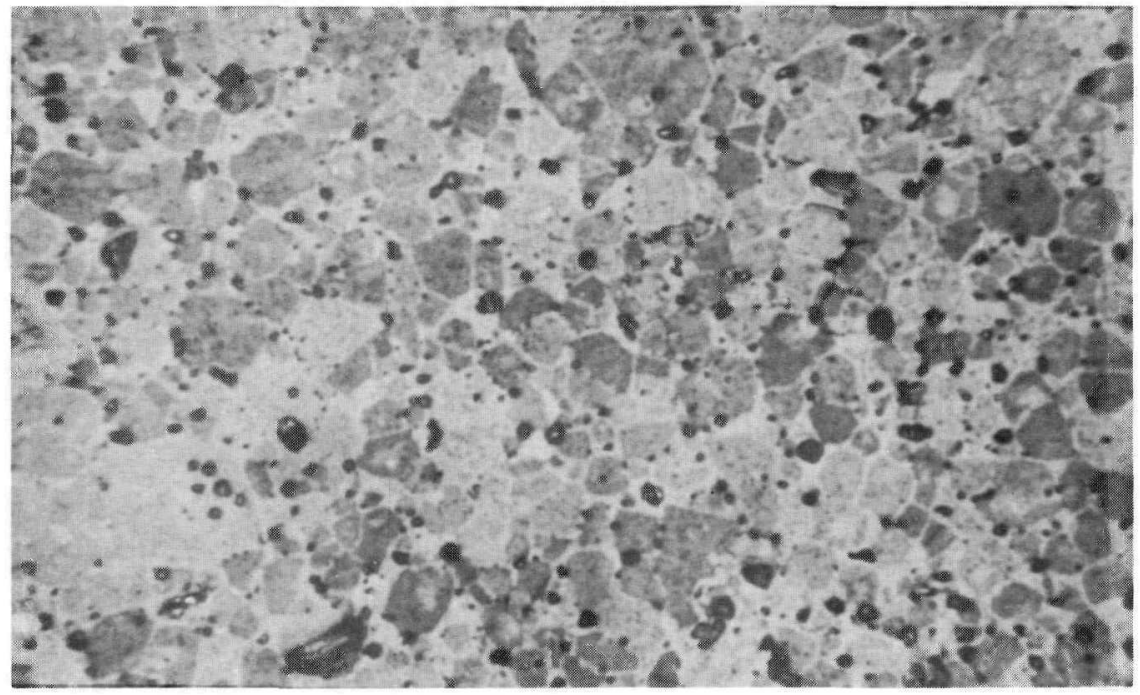

Pellet Center

$500 \times$

$(\mathrm{UPu}) \mathrm{C}$ is gray, $(\mathrm{UPu})_{2} \mathrm{C}_{3}$ is white phase, voids are black

Fig. 15 - Typical Fuel Structure (UNC 80, Pellet 9)

after Irradiation to: $760 \mathrm{w} / \mathrm{cm}(23 \mathrm{kw} / \mathrm{ft})$

$180 \mathrm{w} / \mathrm{g}$

24,200 Mwd/T 


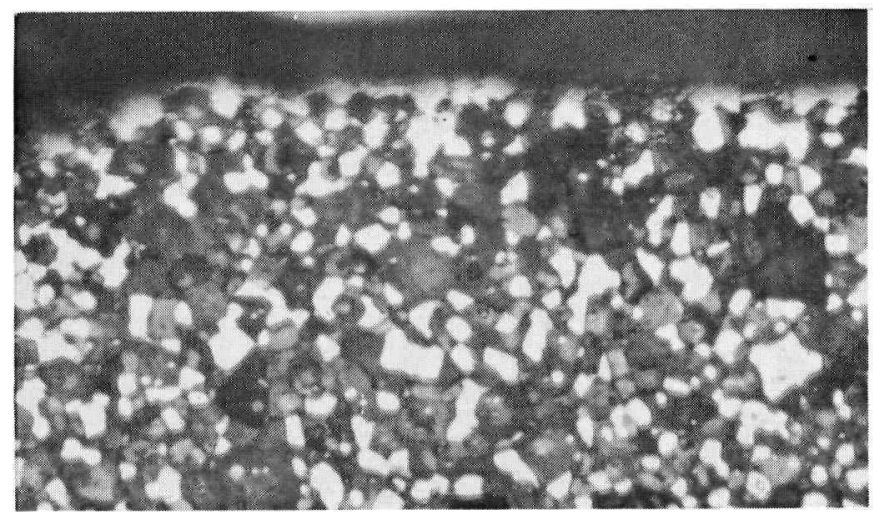

Pellet Edge

$500 \times$

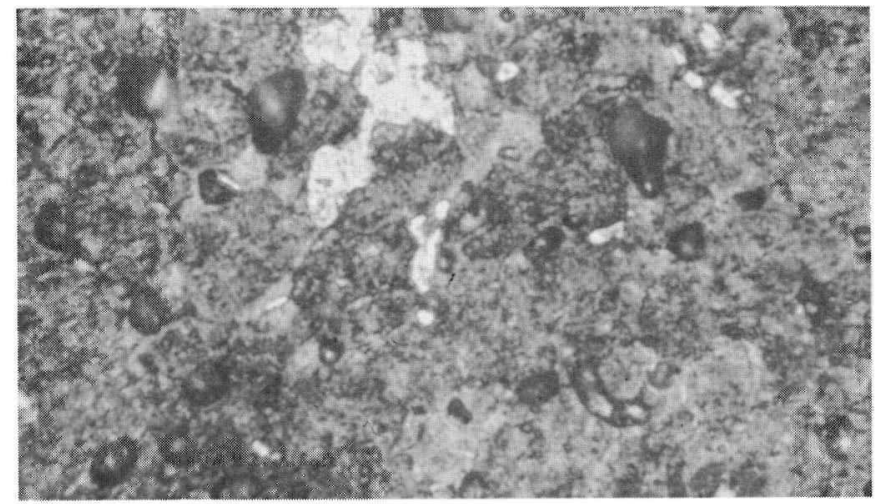

Pellet Center

$500 \times$

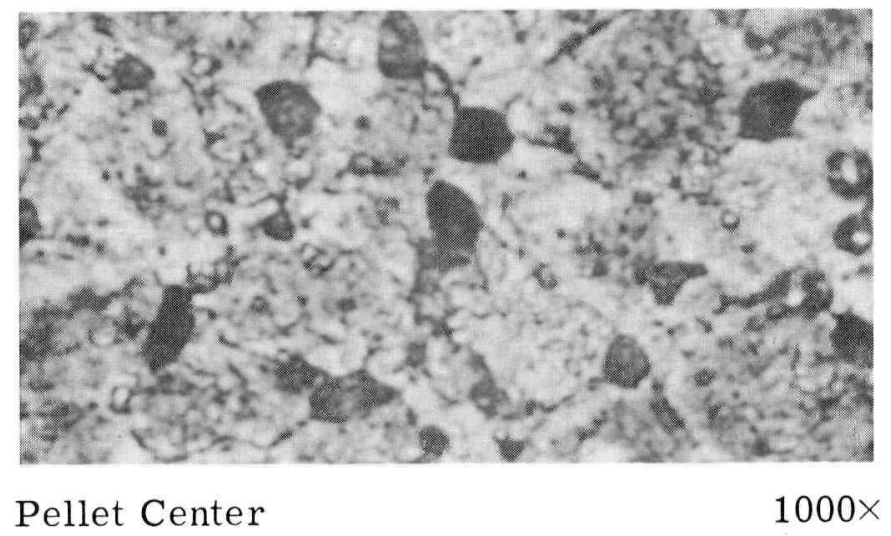

$(\mathrm{UPu}) \mathrm{C}$ is gray matrix, $(\mathrm{UPu})_{2} \mathrm{C}_{3}$ is white phase, voids are black

Fig. 16 - Typical Fuel Structure (UNC 80, Pellet 27) after Irradiation to: $920 \mathrm{w} / \mathrm{cm}(28 \mathrm{kw} / \mathrm{ft})$

$225 \mathrm{w} / \mathrm{g}$

$30.000 \mathrm{Mwd} / \mathrm{T}$ 
results are shown in Fig. 17 along with the photomacrograph of the specimen. The lack of plutonium or fission product redistribution confirms previous ther mal irradiation results.

\subsubsection{Burnup Analysis}

The (UPu)C burnup analyses were based on the comparison of $\mathrm{Nd}^{148}$ and the $\mathrm{U}$ and $\mathrm{Pu}$ isotopes to unirradiated controls. General Electric's Vallecitos Laboratories made the analyses on solutions of entire pellets prepared by Battelle. The results are given below.

\begin{tabular}{|c|c|c|c|c|c|}
\hline \multirow{2}{*}{$\begin{array}{l}\text { Rod } \\
\text { No. }\end{array}$} & \multirow{2}{*}{$\begin{array}{c}\text { Pellet } \\
\text { No. }\end{array}$} & \multicolumn{2}{|c|}{ Atom $\%$ Fissioned } & \multicolumn{2}{|c|}{$10^{20}$ fiss $/ \mathrm{cm}^{3 *}$} \\
\hline & & $\mathrm{Nd}^{148}$ & U,Pu Isotopic & $\mathrm{Nd}^{148}$ & $\mathrm{U}, \mathrm{Pu}$ Isotopic \\
\hline 78 & 35 & 2.82 & 3.44 & 9.0 & 11.0 \\
\hline 79 & 36 & 2.00 & 2.60 & 6.4 & 8.3 \\
\hline 80 & 32 & 2.98 & 3.46 & 9.5 & 11.1 \\
\hline
\end{tabular}

The axial variation of burnup was calculated for each rod, based on the flux profile reported in Reference 3. The accuracy of the $\mathrm{Nd}^{148}$ analysis is reported to be $\pm 10 \%$ while that of the isotopic analysis is reported to be $\pm 15 \%$. Using these error bands, the most probable burnup was calculated and plotted in Figs. 3, 4, and 5. The peak burnups are a factor of 1.15 higher than the average for each rod and both are given in Table 9 . The peak burnup of the highest power rod was $10.6 \times 10^{20}$ fiss $/ \mathrm{cm}^{3}(30,000 \mathrm{Mwd} / \mathrm{T})$ while that of the lower power rod was $7.4 \times 10^{20}$ fiss $/ \mathrm{cm}^{3}(22,000 \mathrm{Mwd} / \mathrm{T})$.

\subsubsection{Temperature Analysis}

The temperature of fuel in helium-bonded rods with large fuel-clad gaps changes continuously. At startup the fuel operates at the highest temperature of its life cycle. As the fuel swells and fills up the helium gap, its temperature drops rapidly until it contacts the clad.

${ }^{*} \mathrm{~cm}^{3}$ of $(\mathrm{UPu}) \mathrm{C}$. 
TABLE 9 - SUMMARY OF BURNUP ANALYSES

UNC 78

UNC 79

UNC 80

Average Fuel Burnup:

Reactor data

fiss $/ \mathrm{cm}^{3}$

$(\mathrm{Mwd} / \mathrm{T})$

$8.7 \times 10^{20}$

$(25,000)$

$5.9 \times 10^{20}$

$8.7 \times 10^{20}$

analysis

fiss $/ \mathrm{cm}^{3}$

(Mwd/T)

$8.2 \times 10^{20}$

$(24,000)$

$(17,000)$

$(25,000)$

$\mathrm{U}, \mathrm{Pu}$ analysis

fiss $/ \mathrm{cm}^{3}$

$(\mathrm{Mwd} / \mathrm{T})$

$9.8 \times 10^{20}$

$(29,000)$

$5.8 \times 10^{20}$

$8.4 \times 10^{20}$

$(17,000)$

$(25,000)$

Probable burnup

$$
\begin{aligned}
& \text { fiss } / \mathrm{cm}^{3} \\
& (\mathrm{Mwd} / \mathrm{T})
\end{aligned}
$$

$8.8 \times 10^{20}$
$(26,000)$

$7.5 \times 10^{20}$

$(22,000)$

$9.7 \times 10^{20}$

$(28,000)$

Peak Fuel Burnup:

Probable burnup

fiss $/ \mathrm{cm}^{3}$

$10.2 \times 10^{20}$

$(\mathrm{Mwd} / \mathrm{T})$

$(29,000)$

$7.4 \times 10^{20}$

$(21,000)$

$10.6 \times 10^{20}$

$(30,000)$ 


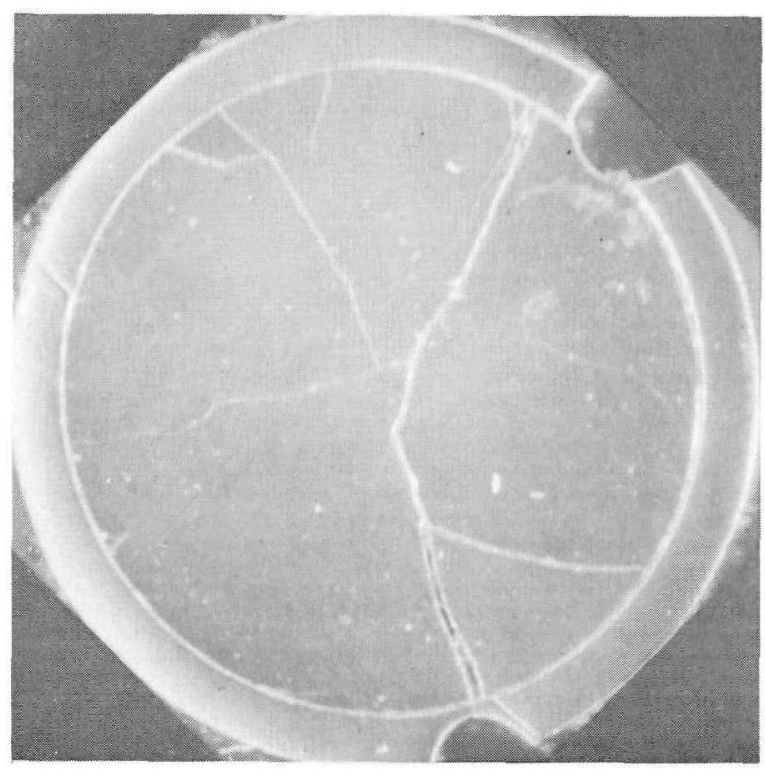

Metallographic Section* $(3 \times)$

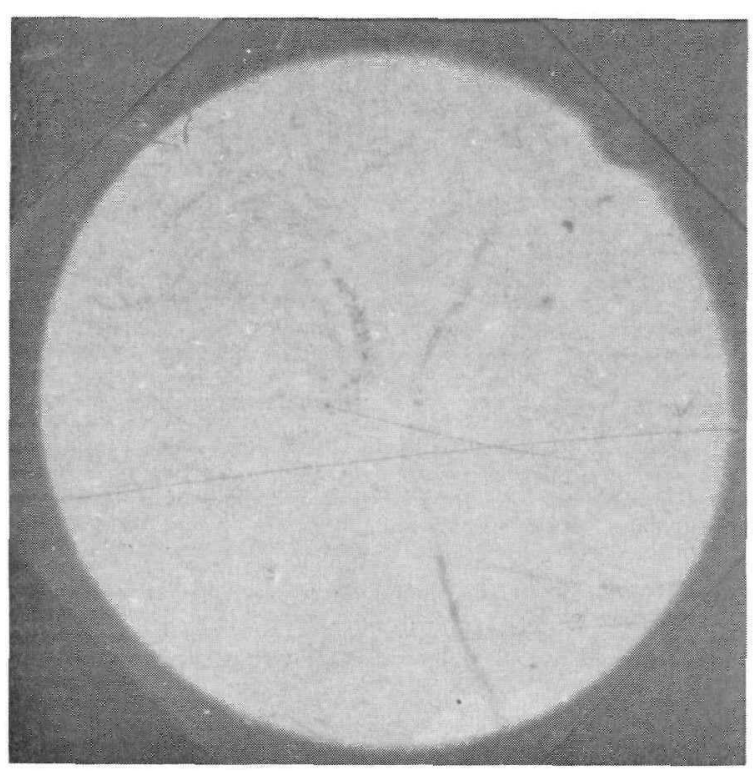

Alpha Autoradiograph

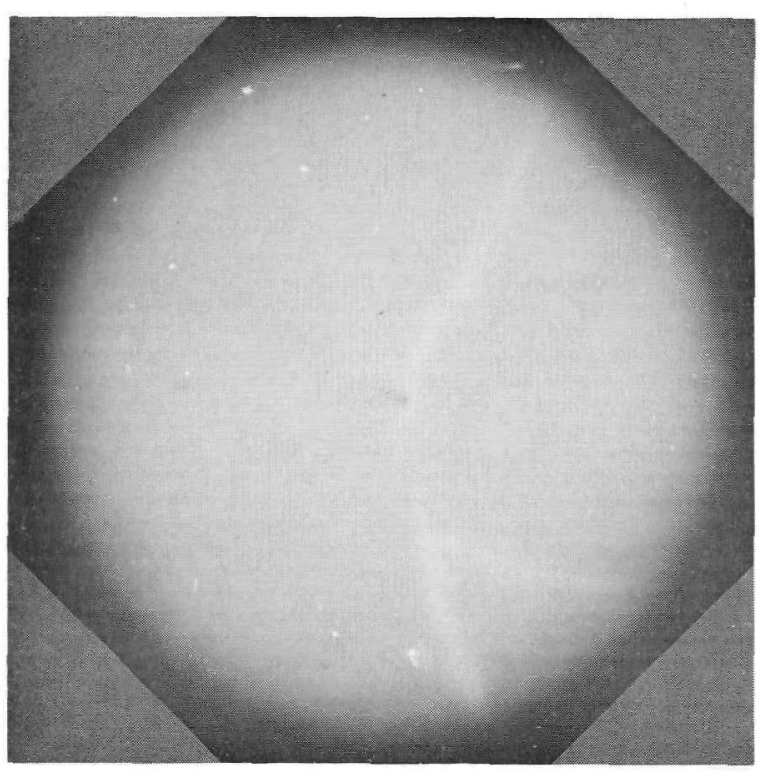

Beta-Gamma Aut.sradiograph

*Grooves in clad from post-irradiation slitting.

Fig. 17 - Typical Plutonium and Fission Product Distribution

(UNC 78, Pellet 2) after Irradiation to: $620 \mathrm{w} / \mathrm{cm}(19 \mathrm{kw} / \mathrm{ft})$

$150 \mathrm{w} / \mathrm{g}$

$19,500 \mathrm{Mwd} / \mathrm{T}$ 
After clad contact is made, temperature drop is only slight and interface pressure dependent.

Two things could happen to prevent the temperature from dropping: the gas gap conductivity could decrease by fission gas release, and the fuel conductivity could decrease with burnup. Fission gas release during the initial burnup period is low, less than $1 / 2 \%$, and does not affect gas gap conductivity. The effect of burnup on fuel conductivity is not significant up to $\sim 8000 \mathrm{Mwd} / \mathrm{T}$ and is likely to be insignificant above that, compared to the increase in the gas gap conductivity.

The fuel temperature history therefore was calculated assuming constant fuel conductivity and a gas gap containing helium only. A simplified assumption of a linear swelling rate of $1.8 \% \Delta \mathrm{V} / \mathrm{V}$ was made.

The fuel temperature was calculated using an iterative technique which takes into account the temperature dependence of the helium gap conductivity and the thermal expansion of both fuel and clad. ${ }^{4}$ Pre-irradiation thermal expansion and conductivity were used since reliable post-irradiation values were not available.

The change in the fuel centerline temperature with burnup is shown in Fig. 18. The rate of temperature change for UNC 79 is less since the initial gap is larger. The change in temperature distribution with burnup was also calculated for each pellet used as a metallographic specimen and plotted as a function of fractional radius. Plots for UNC 80 given in Figs. 19 and 20 correspond to the pellets experiencing minimum and maximum temperatures of the rod, respectively. The solid lines in the figures are the beginning and end-of-life temperature distributions. The area in between these two curves represents the distribution at any intermediate time and can be imagined to be made up of a series of curves of the same shape. 


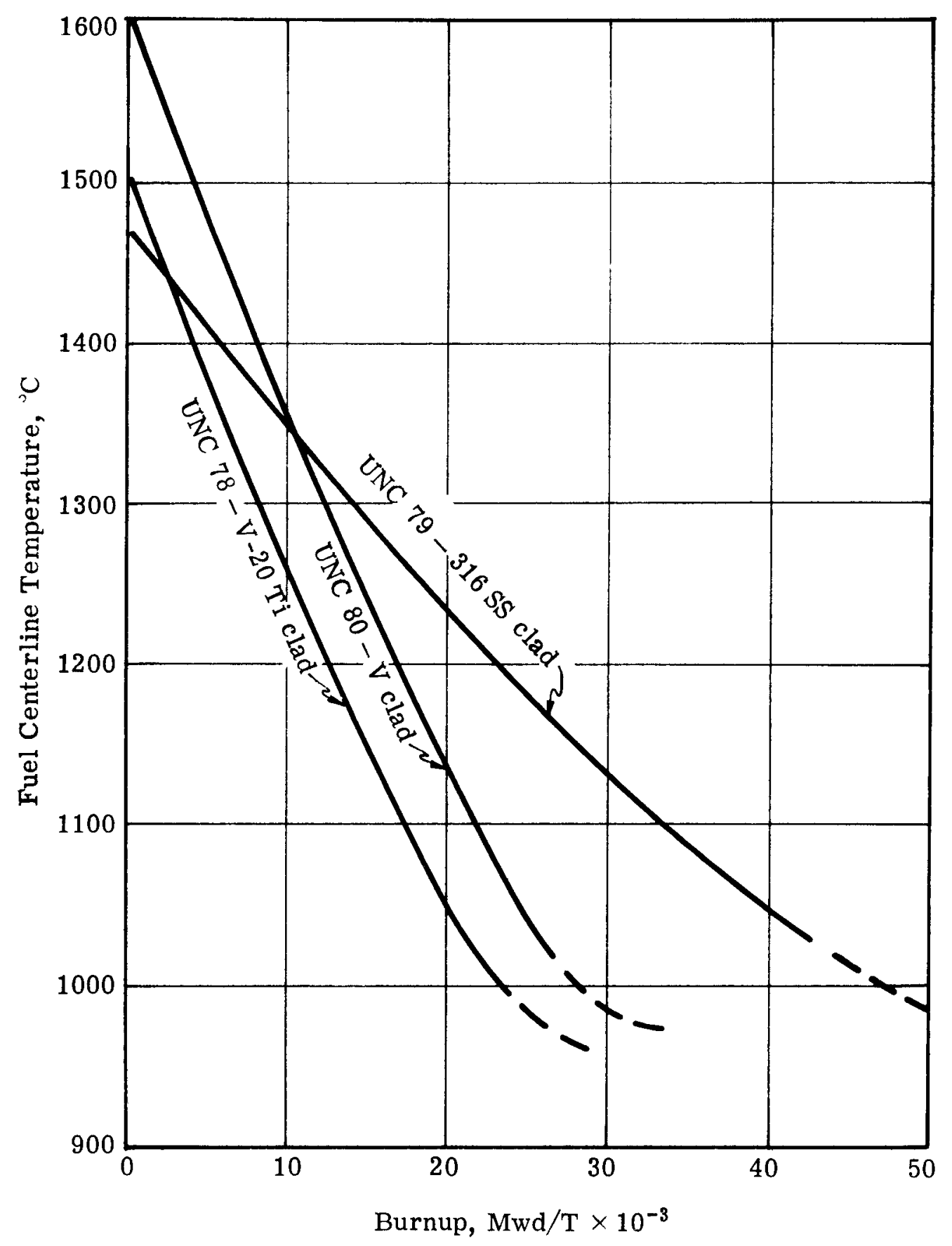

Fig. 18 - Fuel Centerline Temperature vs Burnup (UNC 78, $79,80)$ 


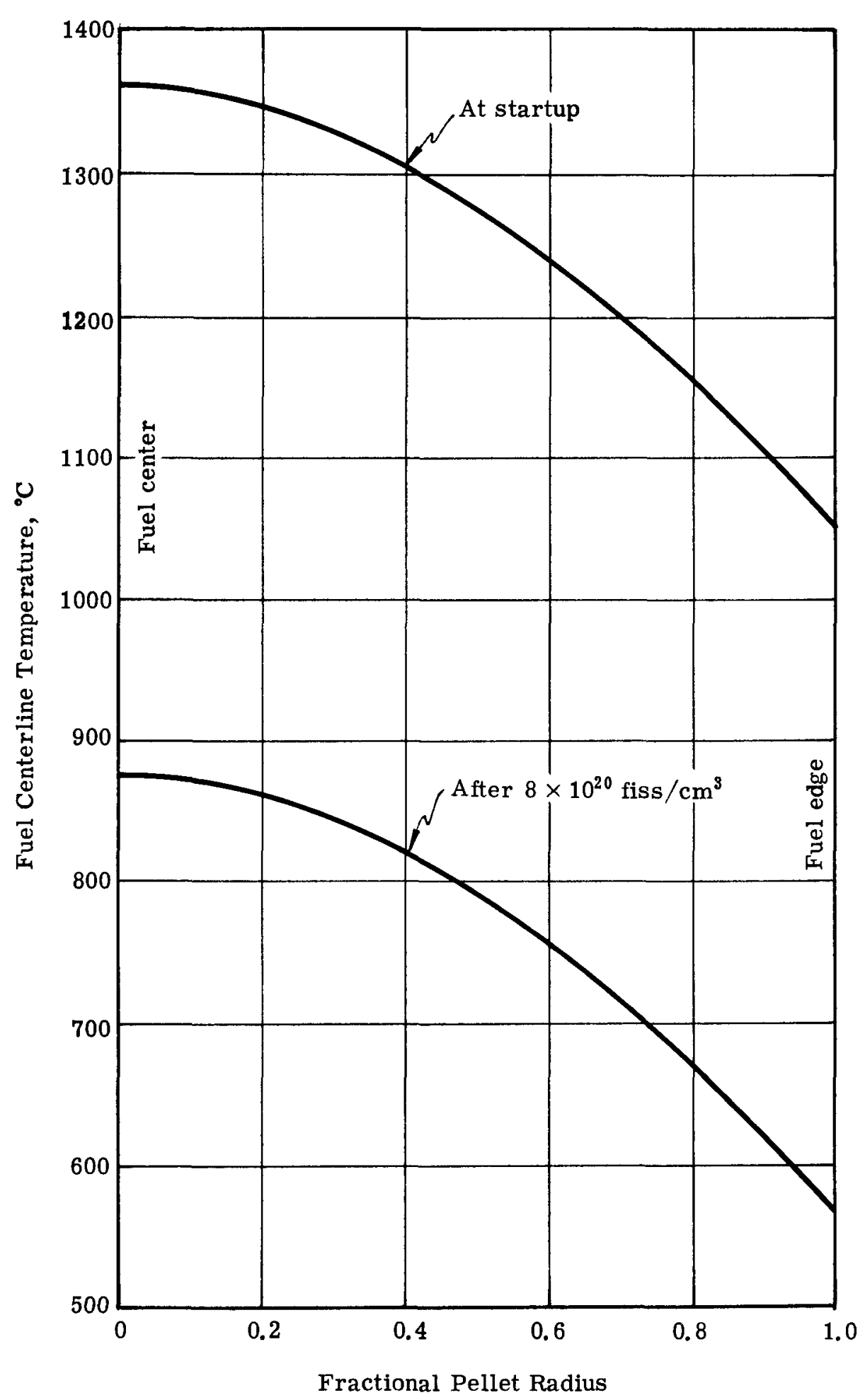

Fig. 19 - Change in Radial Fuel Temperature Distribution with Time (UNC 80, Pellet $9,760 \mathrm{w} / \mathrm{cm}$ ) 


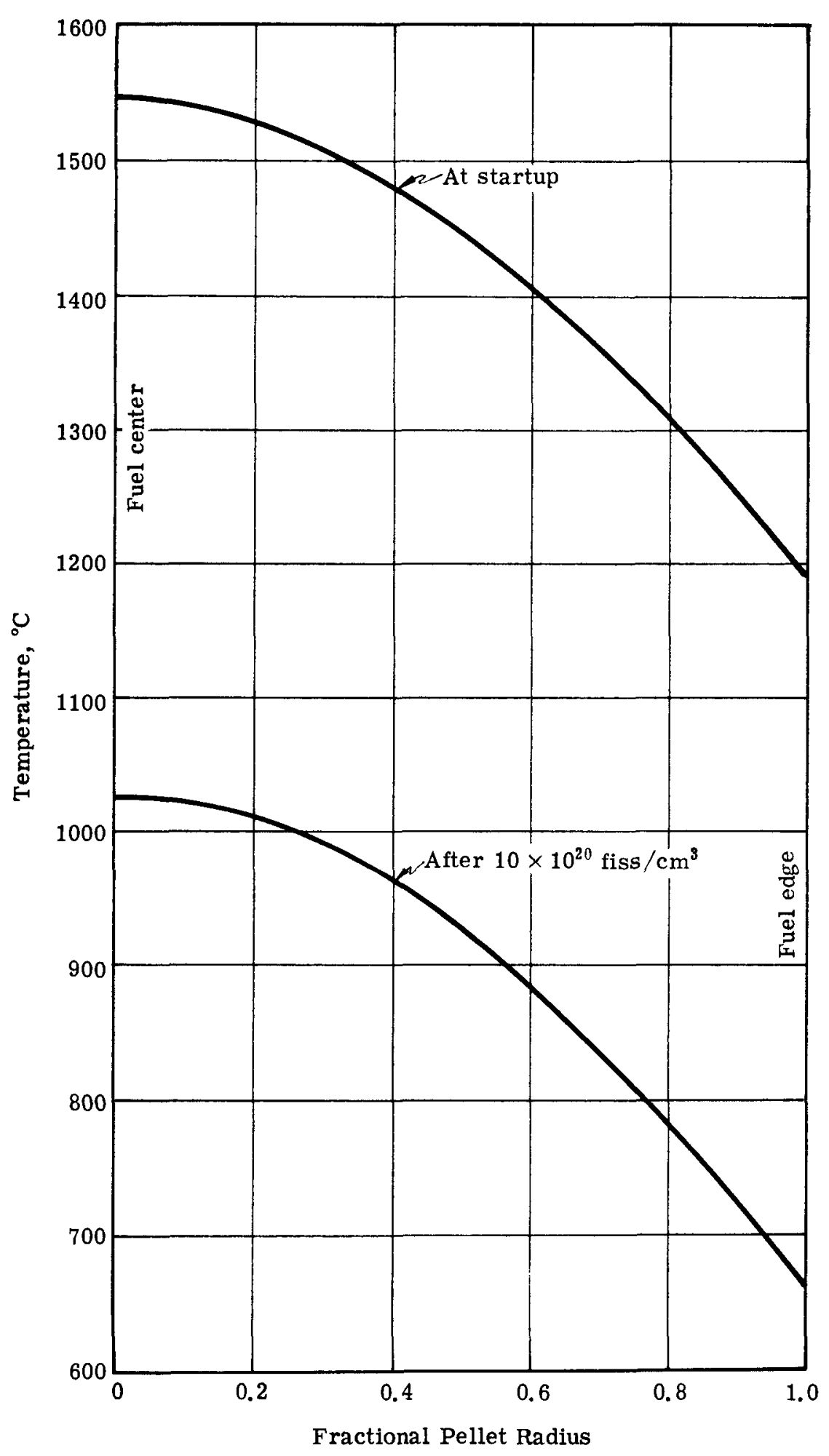

Fig. 20 - Change in Helium-Bonded Carbide, Radial Temperature Distribution with Time (UNC 80, Pellet $27,850 \mathrm{w} / \mathrm{cm}$ ) 
The curves show that although startup temperatures are high, they drop rapidly to equilibrium values of about $1000^{\circ} \mathrm{C}$, independent of power.

\subsection{CLAD PERFORMANCE}

\subsubsection{Structure and Compatibility}

Metallographic examination of the clad was made on samples taken from the region opposite to the high burnup portion of the fuel rod and from the gas plenum. Longitudinal and radial sections were examined. Figs. 3, 4, and 5 show the sample locations.

The type 316 stainless steel from Rod 79 had typical stainless steel microstructure, as shown in Fig. 21. The re was no evidence of fuel-clad reactions. The inside, and to a lesser extent the outside, surface of the sample taken opposite the fuel had more rapidly etching grain boundaries than the sample from the gas plenum. This is probably due to sensitization caused by operation at temperatures of $550^{\circ}$ to $600^{\circ} \mathrm{C}$ for $2850 \mathrm{hr}$.

The vanadium samples did not show any evidence of fuel-clad reactions. The sample from the fueled and gas plenum regions were the same as the unirradiated control (Fig. 22).

The fueled region of the vanadium $-20 \mathrm{w} / \mathrm{o}$ titanium clad, UNC 78 , interacted with the fuel, while the plenum region was unaffected (Fig. 23). The interaction of 1 to 2 mils was uniform and did not extend along grain boundaries toward the outside surface. This interaction was unlike that found in out-of-pile tests which produced intergranular carbide precipitation. The in-pile reaction is probably related to the presence of sodium in the annulus. The fuel showed no depletion of sesquicarbide from the surface.

The vanadium and $\mathrm{V}-20 \mathrm{w} / \mathrm{o} \mathrm{Ti}$ spacer discs from the ends of the fuel stacks 

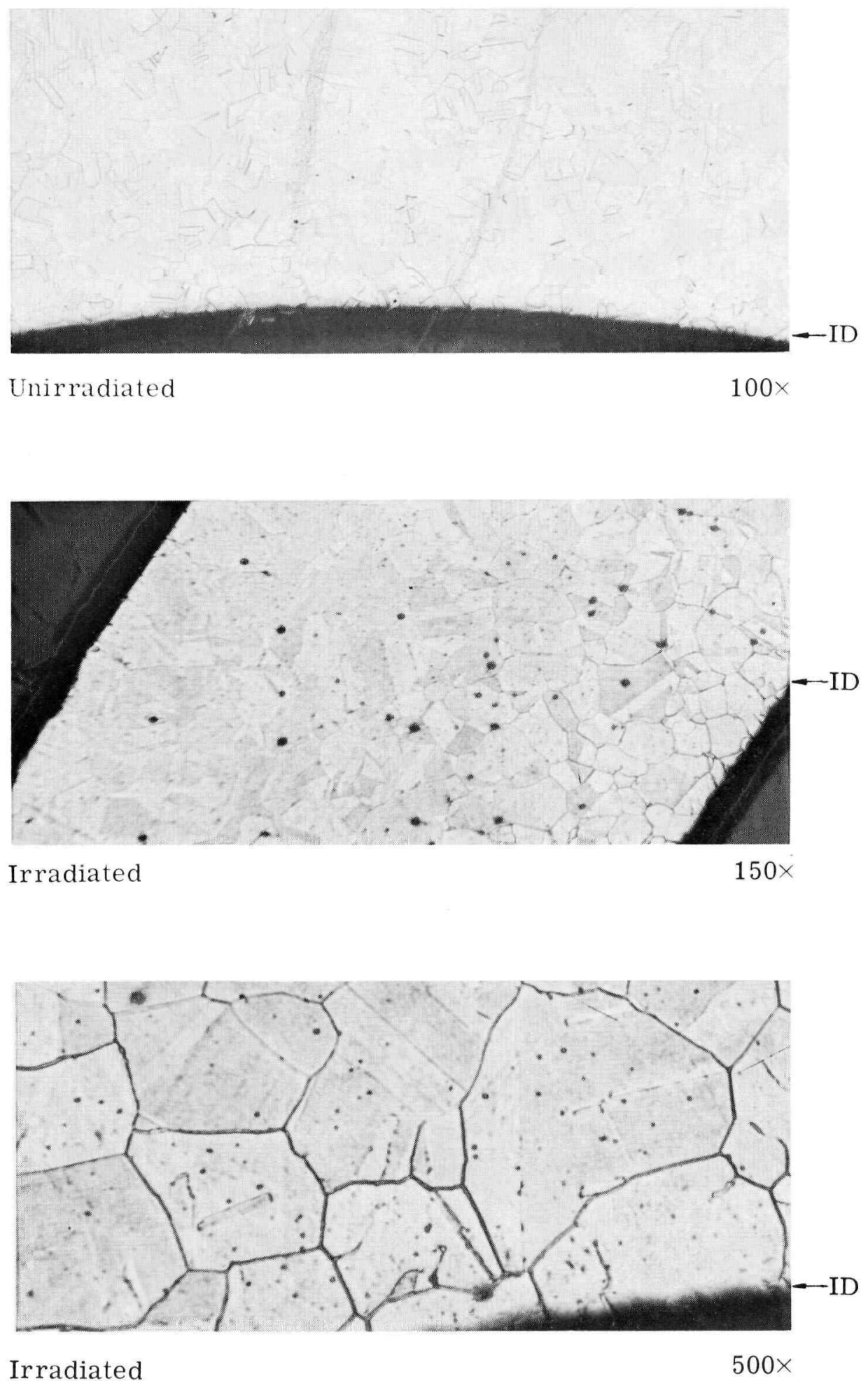

Fig. 21 - Type 316 Clad Adjacent to Fuel after Irradiation $\left(1.7 \times 10^{22} \mathrm{nvt}, 650^{\circ} \mathrm{C}\right.$ at $\mathrm{ID}, 610^{\circ} \mathrm{C}$ at $\mathrm{OD}, 2850 \mathrm{hr}$ ) 

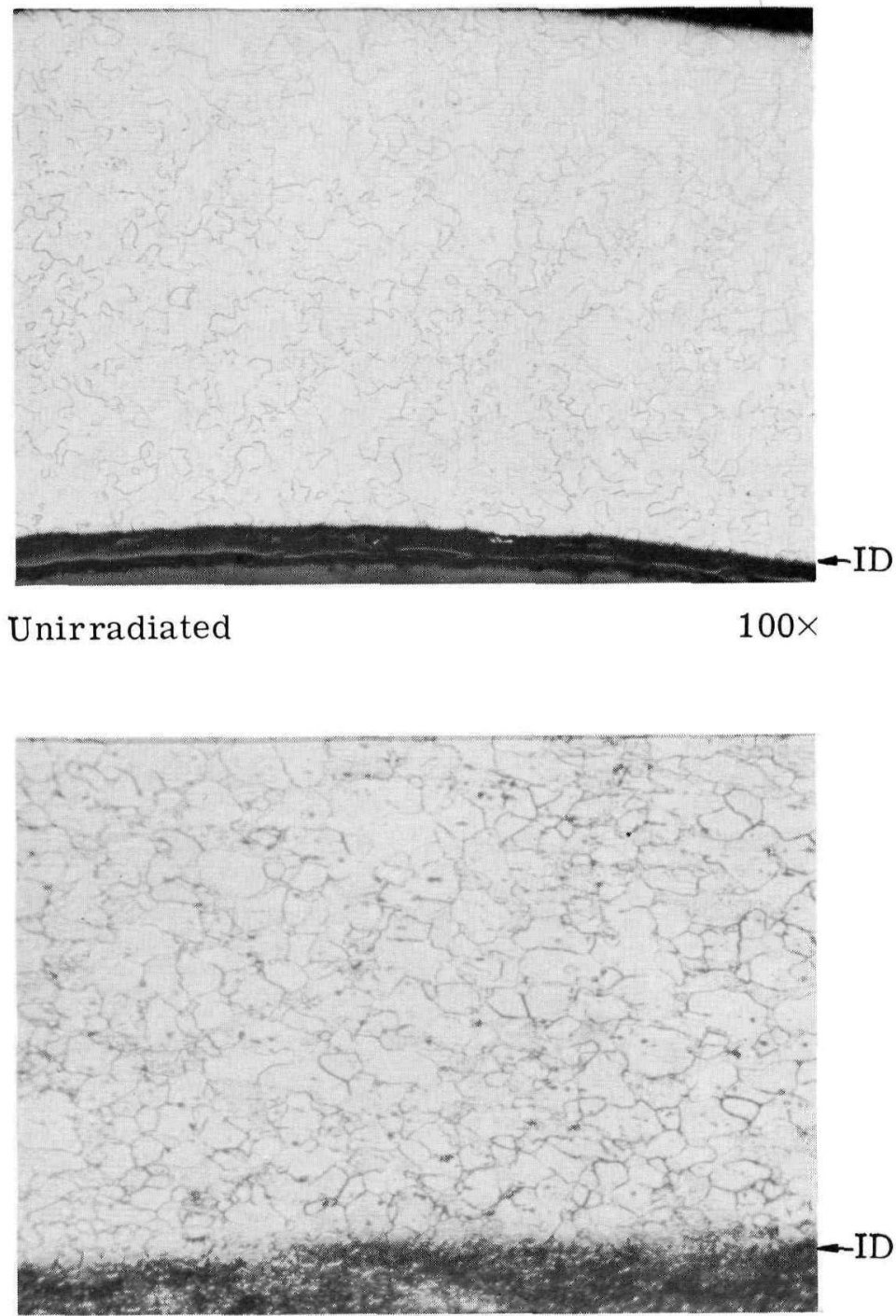

Ir radiated

$150 \times$

Fig. 22 - Vanadium Clad Adjacent to Fuel after Irradiation $\left(1.7 \times 10^{22} \mathrm{nvt}, 650^{\circ} \mathrm{C}\right.$ at $\mathrm{DD}, 590^{\circ} \mathrm{C}$ at $\mathrm{OD}$, $2850 \mathrm{hr}$ ) 


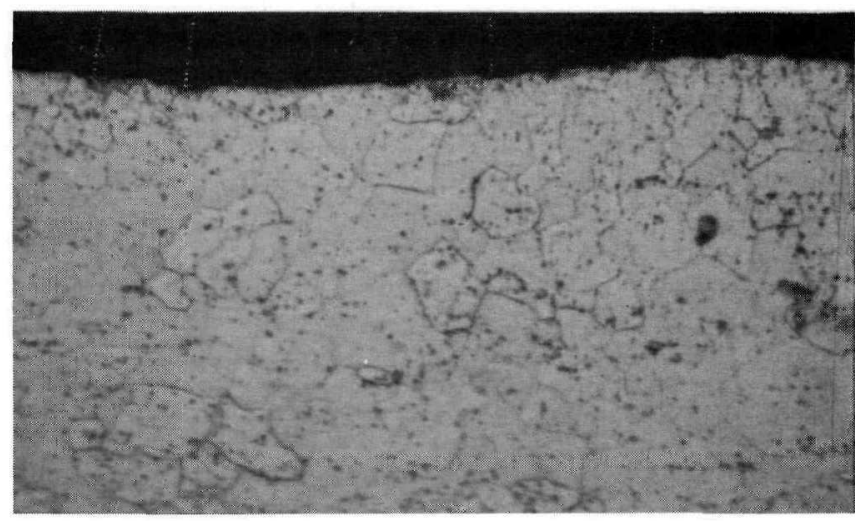

Unirradiated

$500 \times$
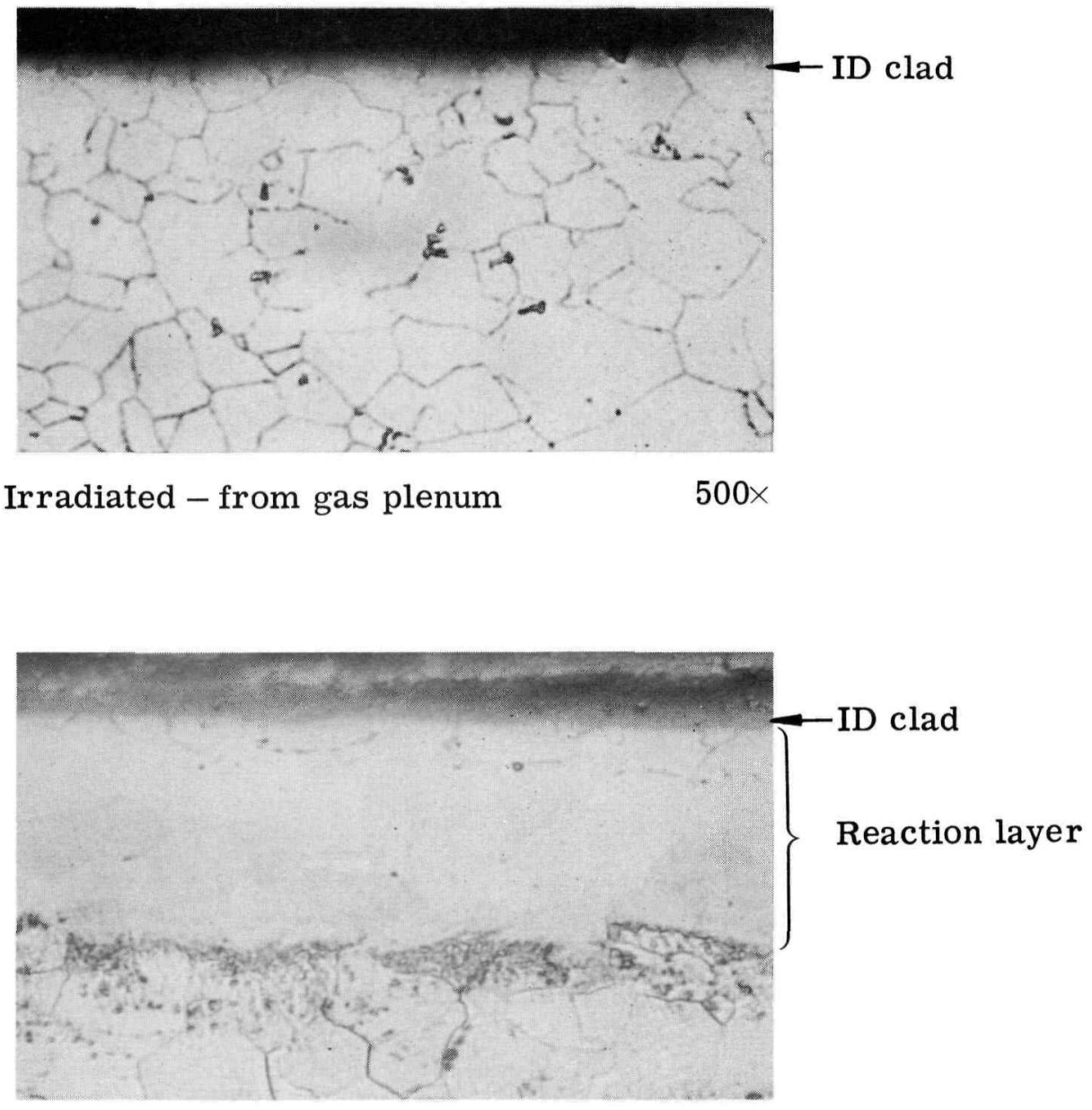

Irradiated - adjacent to fuel

$500 \times$

Fig. 23 - Vanadium-20 w/o Titanium Clad after

Irradiation $\left(1.7 \times 10^{22} \mathrm{nvt}, 650^{\circ} \mathrm{C}\right.$ at $\mathrm{ID}, 590^{\circ} \mathrm{C}$ at $\mathrm{OD}, 2850 \mathrm{hr}$ ) 
were examined metallographically. Little or no interaction was found. In this case, the interaction was in the form of carbides in the grain boundaries at the hottest region opposite the fuel.

Further investigations of the interactions are not planned, since $\mathrm{V}-20 \mathrm{w} / \mathrm{o}$ $\mathrm{Ti}$ is an undesirable clad for carbides, based on the out-of-pile incompatibility alone.

\subsubsection{Microhardness}

Microhardness measurements were made on the clads from each rod in the gas plenum area and the fueled area. These values are presented in Table 10 along with hardness data for unirradiated material.

In general, the irradiated clad was harder than the unirradiated material. Also, the $\mathrm{V}-20 \mathrm{w} / \mathrm{o} \mathrm{Ti}$ clad and the type 316 stainless steel clad were harder in the fueled region than in the gas plenum region, while the vanadium clad was fairly uniform in hardness. The reaction zone on the inside edge of the fueled region of $\mathrm{V}-20 \mathrm{w} / \mathrm{o} \mathrm{Ti}$ alloy clad was about $70 \mathrm{KHN}$ harder than the unreacted clad.

\subsubsection{Bend Tests}

Relative ductilities of the clads from all fuel rods were determined by bending at room temperature a longitudinal section of clad $180^{\circ}$ around a 0.5 -in. diam eter bar so that the clad inner surface became the convex side of the bend. All of the clad samples survived the bend tests without cracking. As evidenced by these bend tests and the slitting operations, the stainless steel was very ductile, the vanadium moderately ductile, and the $\mathrm{V}-20 \mathrm{w} / \mathrm{o}$ Ti less ductile. 
TABLE 10 - KNOOP MICROHARDNESS OF CLADS

$$
\text { (100-g Load) }
$$

\begin{tabular}{|c|c|c|c|c|c|c|c|}
\hline Clad Type & $\begin{array}{c}\text { Sample } \\
\text { Location }\end{array}$ & $\begin{array}{l}\text { Inside } \\
\text { Edge }\end{array}$ & $\begin{array}{l}\text { Inside } \\
\text { Fourth }\end{array}$ & Middle & $\begin{array}{c}\text { Outside } \\
\text { Fourth }\end{array}$ & $\begin{array}{c}\text { Outside } \\
\text { Edge }\end{array}$ & Unirradiated \\
\hline \multirow[t]{2}{*}{$\mathrm{V}-20 \mathrm{w} / \mathrm{o} \mathrm{Ti}$} & Fuel region & $320^{*}$ & 243 & 243 & 249 & 255 & \multirow{2}{*}{189} \\
\hline & Gas plenum & 189 & 222 & 222 & 222 & 227 & \\
\hline \multirow[t]{2}{*}{ Type 316} & Fuel region & 240 & 203 & 233 & 249 & 246 & \multirow{2}{*}{153} \\
\hline & Gas plenum & 212 & 199 & 187 & 197 & 197 & \\
\hline \multirow[t]{2}{*}{ Vanadium } & Fuel region & 161 & 143 & 148 & 151 & 112 & \multirow{2}{*}{136} \\
\hline & Gas plenum & 142 & 158 & 164 & 166 & 149 & \\
\hline
\end{tabular}

*Reaction zone. 


\section{REFERENCES}

1. Cihi, J., Hurwitz, S., Rosh, D. and Strasser, A.: The Design and Fabrication of Three (UPu)C Pilot Experiments for EBR-I, UNC-5137 (Oct. 1965).

2. Strasser, A. and Cihi, J.: Carbide Fuel Development - Final Report, UNC-5134, Vol. II (Oct. 1965).

3. Guide for Irradiation Experiments in Experimental Breeder Reactor II, Rev. 2 (Oct. 1965).

4. Andersen, J., Cherry, B., Cihi, J., Powers, R. and Stahl, D.: Irradiation of High-Density (UPu)C in EBR-II - Design and Fabrication Report of Rods 81 through 90, UNC-5170 (Mar. 1967). 
U. S. Atomic Energy Commission

New York Operations Office

376 Hudson Street

New York, New York 10014

Attn: J. Wasser . . . . . . . . . . . . . . . . . . . . 2

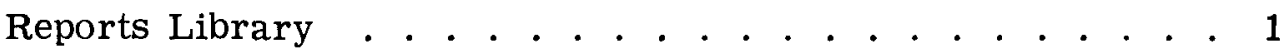

U. S. Atomic Energy Commission

N. Y. Patents Group

Upton, L. I., N.Y. 11973 . . . . . . . . . . . . . . . . . . . 1

U. S. Atomic Energy Commission

Division of Technical Information Extension

P. O. Box 62

Oak Ridge, Tennessee 37830 . . . . . . . . . . . . . . . . . 3

U. S. Atomic Energy Commission

Division of Reactor Development and Technology

Washington, D. C. 20545

Attn: E. E. Sinclair. . . . . . . . . . . . . . . . . . . . 1

J. M. Simmons . . . . . . . . . . . . . . . . . . . 2

A. Giambusso . . . . . . . . . . . . . . . . 1

G. W. Wensch . . . . . . . . . . . . . 1

R. F. Sweek . . . . . . . . . . . . . . . . . 1

M. A. Rosen . . . . . . . . . . . . . . . . . . 1

D. K. Magnus . . . . . . . . . . . . . . . . . 1

U. S. Atomic Energy Commission

Argonne National Laboratory

Argonne, Illinois 60439

Attn: L. R. Kelman, LM FBR Program Office . . . . . . . . . . . 1

Dr. D. F. Cope, RDT Senior Site Representative

Oak Ridge National Laboratory

Post Office Box X

Oak Ridge, Tennessee 37830 . . . . . . . . . . . . . . . . . 1 
Mr. M. E. Jackson

RDT Site Representative USAEC

9800 South Cass Avenue

Argonne, Illinois 60439. . . . . . . . . . . . . . . . . . . . . . . . 1

Mr. P. G. Holstead

RDT Site Representative, USAEC

Pacific Northwest Laboratory

Post Office Box 999

Richland, Washington 99852 . . . . . . . . . . . . . . . . . . 1

Mr. R. L. Morgan

RDT Senior Site Representative, USAEC

Canoga Park Area Office

Post Office Box 951

Canoga Park, California 91305 . . . . . . . . . . . . . . . . . . . 1

Mr. D. J. Wille

USAEC RDT Site Offlce

Atomic Power Development Associates

1911 First Street

Detrolt, Michigan 48226 . + . + . . . . . . . . . . . . . . . . . . 1

RDT site Fepresentative

ANL EBR-I

Idaho Falls, Idaho 89401

Attn: D. A. Moss . , . . . . . . . . . . . . . . . . . . 1

Nuclear Materials and Equipment Corp.

Apollo, Pennsylvania

Attm: K. Puechl . . . . . . . . . . . . . . . . . . . . . . 1

Atomics International

P. O. Box 309

Canoga Park, California 91304

Attn: H. Pearlman , . . . . + . . . . . . . . . . . . . . . . . I

U. S. Atomic Energy Commission

Argonne National Laboratory

Argonne, Illinois 60439

Attn: M. Nevitt. . . . . . . . . . . . . . . . . . . . . . . . 1

J. H. Kittel . . . . . . + . . . . . . . . . . . . . . . 2

Battelle Memorial Institute

505 King A venue

Columbus, Ohio 43201

Attn: D. L. Keller . . . + . . . . . . . . . . . . . . . . . 1 
General Atomic Division

General Dynamics Corporation

Post Office Box 608

San Diego, California

Attn: J. Siltanen . . . . . . . . . . . . . . . . . . . . . . 1

Atomic Power Development Associates

1911 First Street

Detroit, Michigan 48226

Attn: A. A. Shoudy . . . . . . . . . . . . . . . . . . . 1

General Electric Company

Advanced Products Operation

310 DeGuigne Drive

Sunnyvale, California 94086

Attn: E. Zebroski . . . . . . . . . . . . . . . . . . . . 1

Pacific Northwest Laboratory

Post Office Box 999

Richland, Washington 99352

Attn: W. E. Roake . . . . . . . . . . . . . . . . . . . 1

D. R. de Halas

Oak Ridge National Laboratory

Post Office Box X

Oak Ridge, Tennessee 37830

Attn: J. Scott . . . . . . . . . . . . . . . . . . . . . 1

Combustion Engineering Corp.

Nuclear Division

Windsor, Connecticut 06095

Attn: W. E. Chernock . . . . . . . . . . . . . . . . . . . . 1

Babcock and Wilcox Company

Lynchburg, Virginia

Attn: C. Baroch . . . . . . . . . . . . . . . . . . . . . 1

Los Alamos Scientific Laboratory

Post Office Box 1663

Los Alamos, New Mexico 87544

Attn: R. D. Baker . . . . . . . . . . . . . . . . . . 1

D. B. Hall . . . . . . . . . . . . . . . . . . . . . 1

Lawrence Radiation Laboratory

Post Office Box 808

Livermore, California 94551

Attn: A. Rothman . . . . . . . . . . . . . . . . . . . . . . . 1 
Westinghouse Electric Corporation

Post Office Box 355

Pittsburgh, Pennsylvania 15230

Attn: W. E. Ray . . . . . . . . . . . . . . . . . . . . . . 1

Recipients under UKAEA/USAEC and

In accordance

EURATOM/USAEC Fast Breeder Reactor with previous

Information Exchange Arrangement . . . . . . . . . . . . instructions 